\title{
Communism as the Unhappy Coming
}

\author{
Simeon Djankov ${ }^{\mathrm{a}} \quad$ Elena Nikolova ${ }^{\mathrm{b}}$
}

March 30, 2018

\begin{abstract}
We show that Eastern Orthodox believers are less happy compared to those of Catholic and Protestant faith using data covering more than 100 countries around the world. Consistent with the happiness results, we also find that relative to Catholics, Protestants and non-believers, those of Eastern Orthodox religion have less social capital and prefer old ideas and safe jobs. In addition, Orthodoxy is associated with leftleaning political preferences and stronger support for government involvement in the economy. Compared to non-believers and Orthodox adherents, Catholics and Protestants are less likely to agree that government ownership is a good thing, and Protestants are less likely to agree that getting rich can only happen at the expense of others. These differences in life satisfaction and other attitudes and values persisted despite the fact that communist elites sought to eradicate church-going in Eastern Europe, since communists maintained many aspects of Orthodox theology which were useful for the advancement of the communist doctrine. The findings are consistent with Berdyaev's $(1933,1937)$ hypothesis of communism as a successor of Orthodoxy.
\end{abstract}

\section{Forthcoming, Journal of Comparative Economics.}

Keywords: attitudes, communism, Eastern Orthodoxy, religion

JEL codes: D02, P35, Z12

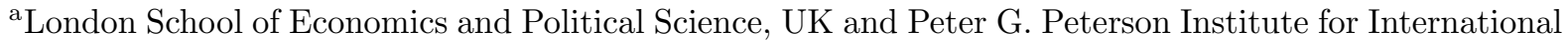
Economics, USA. Email: S.Djankov@lse.ac.uk. We would like to thank Sergei Guriev, Olena Nizalova, Marcus Noland, Jakub Polansky, Nicolas Veron, Andrei Shleifer, seminar participants at Leibniz IOS-Regensburg, anonymous referees, and participants at the conference People Matter: Quality of Life in Post-Transition Economies for useful comments. Elena Nikolova thanks the UCL Centre for Comparative Studies of Emerging Economies for research support on this project. The views expressed in this paper are those of the authors only (in a personal capacity) and not of any organization.

${ }^{\mathrm{b}}$ Central European Labor Studies Institute, Slovakia; Leibniz Institute for East and Southeast European Studies, Regensburg, Germany; and University College London. Email: e.nikolova@ucl.ac.uk. 


\section{Introduction}

Following the pioneering work of Weber (1904), scholars have examined the link between religion and happiness (Campante and Yanagizawa-Drott 2015; Djankov et al. 2016); attitudes toward market economy, work ethic and thrift (Guiso et al. 2003; McCleary and Barro 2006); trust (La Porta et al. 1997); and women and members of other religions (Clingingsmith et al. 2009). A broader literature studies the impact of long-run historical factors on cultural preferences (Becker et al. 2014; Nunn and Wantchekon 2011). Moreover, recent work has argued that culture is an important determinant of economic and political development (Gorodnichenko and Roland 2015; Tabellini 2010). If religion affects preferences, and preferences affect (or even co-evolve with) economic and political institutions (Aghion et al. 2010), then the question of how exactly religion enters into the broader process of institutional evolution deserves scrutiny.

Although the existing scholarship has explained long-run institutional development across countries with a variety of different factors, the literature remains largely silent on the role of religion. For example, high settler mortality, along with the dominance of labor intensive activities such as mining or sugar growing, may have prompted European colonizers to adopt extractive institutions which, once in place, were difficult to change after independence (Engerman and Sokoloff 2000; Acemoglu et al. 2001). Similarly, the quality of political regimes has been linked to redistribution pressures arising from income inequality (Boix 2003), income per capita (Boix 2011), revolutionary threats (Aidt and Franck 2015) and migration (Nikolova 2017).

Using multiple waves of the World Values Survey (WVS) and the 2010 and 2016 rounds of the EBRD-World Bank Life in Transition Survey (LiTS), we investigate the association

of three Christian denominations (Orthodoxy, Catholicism and Protestantism) on personal attitudes and behavior, focusing on satisfaction with life in particular. We also exmamine the 
link between religion and social capital; opinions about change and tradition; and views on government. The LiTS includes all transition countries with the exception of Turkmenistan, along with Turkey, France, Germany, Italy, Sweden and the UK (in 2010), and Turkey, Greece, Cyprus, Italy and Germany (in 2016). The WVS covers nearly 100 countries and territories around the world, including 26 post-communist countries.

Two inter-related findings emerge from our analysis. First, Catholics and Protestants are happier relative to non-believers (which comprise the omitted category in the regressions). Interestingly, the life satisfaction of those of Eastern Orthodox religion is not different from that of the non-religious group. Consistent with these results, we find that, relative to those belonging to the Catholic or Protestant religion and non-believers, Eastern Orthodox respondents have fewer children, less social capital and are more risk-averse. They also prefer old, rather than new, ideas and safe jobs. Orthodox believers have more left-leaning political orientations and a stronger opinion that governments (versus people) should take more responsibility.

Moreover, compared to non-believers, Catholics and Protestants are less likely to agree that government ownership is a good thing, and Protestants are less likely to agree that getting rich can only happen at the expense of others. Along both of these dimensions, Orthodox believers are no different than those who do not follow a particular religion.

Our empirical setting presents a number of advantages. First, the survey data allow us to control for a wide variety of observable characteristics that may be correlated with preferences, such as employment status, self-reported health, educational attainment, urbanity, and parental background (education and membership in the former communist party). ${ }^{1}$ Second, we can include country dummies in all specifications. Our results are therefore less likely to be driven by fixed national characteristics which may explain both the prevalence of a particular Christian denomination and cultural attitudes. Third, we exploit a battery

\footnotetext{
${ }^{1}$ Data on parental background are only available in the LiTS.
} 
of surveys, such as four waves of the World Values Survey (spanning the time period 19952014) and two waves of the Life in Transition Survey (2010 and 2016). Finally, it could be that certain cultural characteristics (discussed below) could have prompted the adoption of different strands of Christianity throughout history, which raises the possibility that our results are contaminated by reverse causality. While we do not have data on preferences before 1989, we believe that this is inherently unlikely for at least two reasons. On the one hand, early kings and khans had little knowledge of the cultural preferences of their respective populations. On the other hand, the decision to adopt Christianity from Byzantium or Rome was driven largely by geo-political considerations, as evidenced, for instance, by Bulgaria's choice of Eastern Christianity in 865.

We then use these data to evaluate among three competing theories linking Orthodoxy and communism. According to Marx, capitalist countries at an advanced stage of development (such as those in Western Europe) were most likely to experience a socialist revolution, which then would lead to the redefinition of social structures and the victory of communism (Marx 1977). Lenin, on the other hand, believed that a joint revolution of the proletariat and the peasantry was necessary to bring social change in Russia (Lenin 1960, p. 40-43). At the same time, Lenin also argued that Orthodox Christianity, which was most prevalent among the peasant population and the exploited working class, must be eradicated completely in order for the class struggle to succeed (Lenin 1960, p. 403-411). In contrast, Berdyaev (1933, 1937) argues that communism succeeded precisely in those countries with a strong Eastern Orthodox tradition. As he explains, "The best type of communist, that is to say, the man who is completely in the grip of the service of an idea and capable of enormous sacrifices and disinterested enthusiasm, is a possibility only as the result of the [Orthodox] Christian training of the human spirit, of the remaking of the natural man by the [Orthodox] Christian spirit" (Berdyaev 1937, p. 170).

Studying the effect of religious differences in communist regimes is important for two 
reasons. First, the literature linking religion and culture has focused on differences across religions, rather than within Christianity itself. As we argue below, theological differences within Christianity are associated with striking attitudinal differences. In addition, little has been written about the role of Eastern Orthodoxy. A number of European countries have Orthodoxy as the prevalent religion, including Belarus, Bulgaria, Georgia, Macedonia, Moldova, Montenegro, Romania, Russia, Serbia and Ukraine, in addition to Cyprus and Greece. $^{2}$ In the US, more than two million people are members of the Orthodox church (Volkov 2005, p. 227), while the number of Orthodox believers globally is more than 250 million. ${ }^{3}$

Second, Orthodoxy and Catholicism embraced different traditions even before $1054 .{ }^{4}$ Catholicism, the Western branch of Christianity, was linked with the Papacy and the Holy Roman Empire, and emphasized the individualistic, legalistic and rationalistic character of Roman antiquity. Catholics have understood the relationship between man and God as a legal one, in which believers follow rules established by God, and any misbehavior requires penance (and justice) supervised by the Church. In contrast, Eastern Orthodoxy has been influenced by Hellenic traditions which have centered on introspection and a communitarian spirit. Rather than highlighting the reciprocal legal obligations between man and God, Orthodox theology emphasizes exchanges based on love and devotion (Janos 2000, p. 3839).

Our argument builds on the idea that deep-rooted theological differences between Orthodoxy and the other two Christian denominations are responsible for differences in attitudes

\footnotetext{
${ }^{2}$ There is no difference among national Eastern Orthodox churches in terms of doctrine, tradition and worship. The key word is Orthodox, while a national designation of the kind Greek Orthodox or Russian Orthodox is of secondary consideration (Kallistos 1993). The Oriental Orthodox Church (which is beyond the scope of this paper) has a different theology compared to the Eastern Orthodox Church.

${ }^{3}$ See the Pew Research Center Report on Global Christianity, December 2011, p. 21, which is available at http://www.pewforum.org/files/2011/12/Christianity-fullreport-web.pdf.

${ }^{4}$ While we do consider Catholicism and Protestantism as separate categories in our empirical analyses, Protestantism was part of the Catholic religion until 1517 and therefore the two religions have very similar theologies.
} 
today. Western Christianity (which gave rise to Catholicism and Protestantism) placed emphasis on rationalism, logical exploration, individualism, and the questioning of established authorities. Eastern Christianity (from which Eastern Orthodoxy originated) was associated with mystical and experiential phenomena, was more affectionate and communitarian, and put less emphasis on law, reason and questioning authorities. Remarkably, these long-run attitudinal differences survived after nearly fifty years of communism. Religious activities were suppressed in most former communist countries during the totalitarian period, as political elites believed that religion was incompatible with the advancement of communism. Marx (1844) writes that, "Religion is the exhausted creature's sigh, the state of animus of a heartless world, the spirit of spiritless situations. Religion is the people's opium." Berdyaev (1933, p. 159) explains that according to Marx, "Religious beliefs reflect human slavery, slavery to the elemental powers of nature and the irrational forces of society. They exist only until man, social man, finally overcomes the elemental and irrational forces which surround him with mystery." Clergy were persecuted, killed and imprisoned and churches were demolished or closed. Church-going was prohibited, and religious education was removed from the school curricula.

At the same time, communist governments maintained those aspects of Orthodox theology - including the emphasis on tradition and communitarianism - which were useful for spreading and solidifying communist ideas. In this regard, Orthodoxy provided a useful condition for the growth of communist regimes. As Janos (2000, p. 326) points out, communism fared much better in the paternalistic and communitarian Orthodox societies of south-east Europe than in the legalistic, contract-based countries in north-west Europe. Communist policies and institutions - collectivization of agriculture, youth socialist organizations, a powerful secret service, and control over internal and external mobility - were highly compatible with pre-existing Orthodox norms, including communitarianism, less reliance on legal exchanges, and higher respect for authority. In many respects, communism can be seen as 
the second coming of Orthodoxy, which we argue is in line with Berdyaev's $(1933,1937)$ hypothesis.

Our work contributes to several strands of the literature. Above all, we contribute to the literature on happiness in transition economies, including Coupe and Obrizan (2016); Djankov et al. (2016); Easterlin (2009); Nikolova (2016). Our results suggest that persistent differences in religious beliefs - via their effect on culture and informal institutions - may also pave the way for distinct political and economic systems, consistent with Berdyaev (1933, 1937). In addition, the findings resonate with work arguing that while in general institutions change slowly (La Porta et al. 1999; Roland 2004), political elites can effectively manipulate both formal institutions (Djankov et al. 2003; Nikolova 2017) and attitudes and beliefs (Adena et al. 2015; Alesina and Fuchs-Schündeln 2007). Our results also relate to a growing scholarship studying how differences in religion and religiosity affect culture (Bénabou et al. 2015; Guiso et al. 2003; La Porta et al. 1997). Finally, we enrich a broader literature on the link between religion and various economic outcomes including growth (Barro and McCleary 2003; Campante and Yanagizawa-Drott 2015; Cantoni 2014), human capital (Becker and Woessmann 2009), investor protection (Stulz and Williamson 2003) and work ethic (Spenkuch 2011).

This paper is organized as follows. The next section presents our theoretical framework. Section 3 describes the data. The fourth section discusses the results, and the final section concludes. 


\section{Theoretical framework}

\subsection{Theological differences between Eastern and Western Chris- tianity}

The Great Schism of 1054 broke the eucharistic unity between East and West Christianity. The primate of Rome, not readily accepted in the East even before the Schism, stopped being of any importance to the Eastern Patriarchates, who accepted Constantinople as 'new Rome' with all the ecclesiastic consequences. However, differences between Orthodoxy and other strands of Christianity (Roman Catholicism, and later, Protestantism) had existed for a long time (Janos 2000). In fact, the rise of individualism in the West - in both family affairs and economic exchange - was mediated by the Catholic Church between the sixth and eleventh centuries. In an attempt to increase the numbers of bequests (particularly from single women), in 597 Pope Gregory I encouraged virginity, prohibited marriage to close kin, close relatives or widows of close kin, and the adoption of children. As a result, Church wealth increased considerably: in France, one third of productive land belonged to the Church at the end of the seventh century. Ecclesiastical wealth prompted Pope Gregory VII not only to separate itself from the state, but also to push for the adoption of legal institutions. Along with the rise of nuclear families and individualism, these developments led to economic growth in the West (Lal 2000, p. 11-12).

These early differences between Eastern and Western Christianity contributed to the distinct positions of the two churches in society and their involvement with secular authority. During the middle of the fourth century, Emperor Constantine turned Christianity from a persecuted sect into the official religion of the Roman Empire. He then shifted the Roman capital from Rome to Constantinople in order to avoid invasions from the North. The Western Roman empire crumbled as a result of Germanic invasions, and the Church acquired an institutional independence which led to a reciprocal relationship with the state. Western 
monarchs solidified their authority via the rituals of coronation and religious anointment, and in exchange respected Church laws (Janos 2000, p. 40-41). The Catholic church was also closely involved in worldly affairs, with the Pope himself often participating in military battles (Janos 2000, p. 40-41). For example, Pope Leo IX, a German aristocrat who ruled central Italy, waged war against his deposed predecessor and his followers in 1049-1050. He also served as the head of an army of Swabians fighting against the Normans in June 1053 and suffered defeat at the Battle of Civitate (Chambers 2006, p. 7-8).

In the East, Byzantium thrived, but the Church remained subordinate to the state, partly because it was unable to acquire the same amount of wealth as its Catholic counterpart. It was accepted that rulers in Orthodox countries were born saintly and did not require sacralization of their authority by the Church. As early as the fourth century, Byzantine monarchs, rather than the Church, were deciding on ecclesiastical matters, and even legislating on heresy and schism. In the last five hundred years of the Byzantine empire, imperial decrees were responsible for forcing out of office nearly one third of all Orthodox patriarchs. For example, St Ignatius became Patriarch of Constantinopole in 847. A fervent critic of iconoclasm and initially appointed by the Empress Mother Theodora, Ignatius fell out of favor and was deposed when Emperor Michael III gained the throne in 858. His successor was Photius, a layman who challenged the Pope's influence over the Orthodox church. When Basil I became emperor in 867, Photius was exiled to Cyprus, and St. Ignatius returned as patriarch. When St. Ignatius died in 877, Photius reconciled with Basil and assumed patriarchal responsibilities once more. He was sent to exile once more in 886 once Leo VI gained the throne (Hussey 2010, p. 70-86). Janos (2000, p. 41) explains that "this blurring of boundaries between state and society anticipated some of the features of modern totalitarianism, and made some of its practices easier to accept when and where they would occur."

What is more, Western and Eastern Christianity differ when it comes to theology. West- 
ern Christian theology placed high emphasis on rationality which culminated in the rise of scholasticism and the institutionalized position of theology in medieval universities in the high Middle Ages. In its early days, Western Christian theology was linked to the work of St Augustine, who taught that the existence of God can be proven by studying nature and by logical inference. Roman law influenced heavily Western Church writers, while philosophy played an important role in theological reasoning (Huntington 1996, p. 69-70). The Reformation and Counter-Reformation were also distinctively Western phenomena: with the arrival of Protestantism in the 16th century, monasticism was repudiated, and believers were urged to express their faith via rational and secular activities (Huntington 1996; Weber 1904). As a result, Protestantism led to religious individualism, innovation and the tendency to question established authorities. The secularization of these religious attitudes was essential for the overall societal evolution of Western Europe, as well as for the breakthroughs associated with the industrial evolution (Markides 2005, p. 180-181). ${ }^{5}$

The rational perspective has been interpreted differently in Eastern Orthodox Christianity. As Huntington (1996, p. 69-70) explains, the Orthodox civilization inherited far less from the Classic civilization compared to the West. First, Orthodoxy puts less emphasis on law and reason. For instance, the Orthodox doctrine of God, and Orthodox theology more generally, never developed in the Western rational sense but were closely associated with mystical, experiental and ascetic phenomena (Berdyaev 1937, p. 9). Eastern Christianity is also more emotional and affectionate, and God is considered to be beyond rational grasping. Moreover, Orthodoxy places a stronger emphasis on tradition and communitarian values. Individuals are therefore less inclined to make decisions freely and critically and to question

\footnotetext{
${ }^{5}$ Empirical studies confirming Weber's hypothesis include Guiso et al. (2003) and Spenkuch (2011). Becker and Woessmann (2009) find that Protestantism (in nineteenth-century Prussia) led to higher economic prosperity, but argue that human capital associated with reading the Bible is the mechanism behind this result. In contrast, Cantoni (2014) shows that within the Holy Roman Empire Protestantism had no effect on economic growth over the period 1300-1900. Chong et al. (2014) provide an empirical measure of Weberian bureaucracy, or a professional bureaucracy with nonpolitical rules of recruitment, promotion, and compensation of employees.
} 
established authorities. As a result, the weaker emphasis on innovation in Orthodoxy may have been responsible for the lack of a Western-type scientific revolution (Markides 2005, p. 182-183). Orthodoxy also pays less attention to legal rights (Berdyaev 1933, p. 150-151).

\subsection{Religion and communism}

Communist regimes regarded church-going as incompatible with communism, and the clergy were persecuted extensively. ${ }^{6}$ Communists considered religion a public problem which must be fought using the tools of militant atheism (Berdyaev 1937, p. 166). According to Lenin, "Religion is one aspect of the spiritual oppression which falls everywhere upon the masses who are condemned to eternal labor for others by their need and their loneliness" (as quoted in Berdyaev (1937, p. 161)). Similarly, Du Bois (1968, p. 286) believed that “...the greatest gift of the Soviet Union to modern civilization was the dethronement of the clergy and the refusal to let religion be taught in public schools." Poland, where communists failed to suppress the Catholic church, was a notable exception. Due to the strength of the Polish church and its role in fostering national identity, communists from the beginning acknowledged that separating the church from the Vatican would be futile (Froese and Pfaff 2001, p. 487-489). The Lutheran Church in East Germany also retained links to churches beyond the communist bloc, which suggests that external links were also important for the survival of religion in some countries. Interestingly, the Cuban Catholic Church has also been very strong, and once again this could be due to the country's ties with the Vatican.

Shortly after the 1917 revolution, the Soviets deprived the Orthodox church of its legal status and the right to own property. Teaching religion was banned in private and public schools (Barmenkov 1983; Froese 2004). In response, Patriarch Tikhon of Moscow excommunicated the government. The Soviet leadership retaliated by killing many bishops, lower

\footnotetext{
${ }^{6}$ We must point out that we do not have data with which to systematically test the insights of this section and therefore must only rely on case-study evidence.
} 
clergy and monks: in the next five years, 28 bishops and 1,215 priests were killed, and 8,000 monks perished in 1922 alone (Pipes 1995; Pospielovsky 1984, 1987). The number of Russian Orthodox churches dropped from 54,000 in 1914 to 7,500 in 1966 (Froese 2004, p. 42).

In Bulgaria, between 1944 and 1950, 153 Eastern Orthodox clergy were tried in court, out of whom 13 were sentenced to death and 13 to life imprisonment. In 1948, out of a total of 2,063 clergy, 1,600 were deemed to be a threat to the communist regime (Metodiev 2012, p. 8). The remainder became informants of the communist secret police: even in the dying days of the communist regime, 11 out of the 15 Orthodox bishops, along with the patriarch, were part of the Bulgarian Secret Service (Metodiev 2012, p. 10). In Romania, following the 1949 "social reorientation" programs monastic seminaries and monasteries were closed down and nearly 4,000 monks and nuns were either jailed or forced to accept a secular life (Stan and Turcescu 2000, p. 1468).

Communist governments did not limit religious persecution to the Orthodox clergy. In Hungary, the communist government nationalized all church lands (including those belonging to the Catholic and Protestant churches) and closed all religious educational institutions in 1948. In addition, churches were prohibited from accepting private support, which made their survival very difficult. By 1951, all clergy had formally agreed to cooperate with the communist regime. Those who objected experienced extreme forms of harassment. Jozef Cardinal Mindszenty, the Roman Catholic Primate of Hungary, was sentenced for life in 1949. Bishop Lojas Ordass, the vice president of the Lutheran World Federation was thrown in prison for two years, and threatened with life imprisonment unless he resigned from his post (Froese 2001, p. 253-254).

Similarly, after 1948 the Czechoslovakian regime seized church property and launched an anti-religious campaign in schools and public life. Although an undisclosed agreement between the communist government and the Vatican allowed religious orders to exist, they were banned in 1950, with their supporters jailed and property nationalized. These policies 
forced some of the clergy to form an underground movement (Winter 1998, p. 219).

In East Germany, the Lutheran church was severely repressed, and as a result by 1989 only $15 \%$ of East German children had been baptized. Although the role of the church remained marginal for the next 40 years, the communist regime was willing to tolerate it provided that ecclesiastical activity did not pose a threat to the state. In addition, the church was able to preserve its ties to the West, including access to financial resources. This came at the cost of concessions to the communists, including loyalty to the government and severing of all ties with the West German church (Froese and Pfaff 2001, p. 491-497).

In Albania, the persecution of all religious communities started when Enver Hoxha came to power in November 1944. The communist party engaged in murder and torture against the clergy. By May 1967, all 2169 religious establishments (churches and mosques) were closed or demolished. In November 1967, all decrees on religion in the constitution were abolished, turning religious practise into an illegal activity. Church property was nationalized and religious education forbidden. By 1971, there were only 14 Catholic priests alive in the country, of whom 12 were in concentration camps and 2 in hiding (Tönnes 1982, p. 247-253).

As we document below, despite this persecution of the clergy, attitudinal difference between Orthodoxy, and Catholicism and Protestantism, persisted. The Catholic church remained strong in Poland, and in several countries ties with the Vatican were not completely severed, which allowed the survival of religion, at least underground. Moreover, communism and Eastern Orthodoxy share many similarities, and the spread and growth of communism in Eastern Europe was aided by the belief system of Orthodox Christianity (Berdyaev 1937, p. 160, 188). In fact, communism resonated far more positively in the Orthodox societies of south-east Europe than in the legalistic, contract-based countries of north-west Europe (Janos 2000, p. 326). According to Berdyaev (1937, p. 170),

"If it were granted that anti-religious propaganda were finally to destroy all traces of Christianity in the soul of the Russian people, and annihilate all religious feeling, then the 
actual realization of communism would become impossible, for no one would be willing to make sacrifices, no one would interpret life as service of a higher purpose, and the final victory would remain with the self-seeking type who thinks only of his own interests. This last type of person, even now, already plays no small part, and the growth of the bourgeois spirit is due to him."

What is more, communist ideologues believed that communism should take the place of Christianity as a belief system (Berdyaev 1937, p. 160). Socialism claimed to be a new, messianic power which could satisfy all of humanity's needs and solve all of its problems. The socialist state and society were considered not secular or civil, but sacred. Berdyaev (1933, 189) writes that "Socialism uses a "sacred" authority and establishes a "sacred" society, in which there is no place for the "lay," for the free, for choice, for the unrestricted activity of human forces."

If Orthodox theology - with its emphasis on tradition and communitarianism - was useful for spreading and solidifying communist ideas, then why did communist governments seek to eradicate church-going from everyday life? One approach was to subordinate churches (whether Orthodox, Protestant or Catholic) to the communist doctrine, by infiltrating it with informants up to the highest level. For example, while the Romanian Communist party regarded the Orthodox Church as a capitalist remnant, it also believed that a church respected by the bulk of the population could be useful in furthering the party's socioeconomic and political goals (Stan and Turcescu 2000). As a result, the Romanian church was enlisted as a promoter of communist policies in exchange for the government's toleration of a certain level of ecclesiastical activities (Flora and Szilagyi 2005, p. 115). Similarly, in 1979 Hungarian Secretary of State Miklos officially explained that churches did not threaten communism anymore and that religion could usefully promote socialist values (Froese 2001, p. 255-256).

More importantly, while communism tried to obliterate religious activity, communists 
engaged in several other policies aimed at promoting the attitudes and values nurtured by the Eastern Orthodox tradition. First, extreme communitarianism was established via the abolition of private property, the nationalization of enterprises and the collectivization of agriculture. Communists believed that cooperative wealth can be distributed "from each according to his ability, to each according to his needs" (Janos 2000, p. 259). With the exception of Yugoslavia and Poland, collectively owned agriculture exceeded $50 \%$ of arable land in most communist countries by 1970. For example, $85.2 \%$ of arable land in Albania was collectivized in 1970, while the corresponding figure for Bulgaria and Hungary was around $68 \%$ (Janos 2000, p. 249).

Second, communist regimes discouraged contractual obligations and legal-based exchanges. For instance, under Stalin, the duty of the party functionary was to expound and re-interpret formal regulations to fit an ever changing party line. Although adherence to the law was stronger in the post-Stalin regime, the Party still performed functions within the administrative and judicial realms which, in a normal legal system, were the prerogative of independent courts. What is more, relationships between superiors and subordinates were not based on formalized accountabilities, but rather on what has been called "crypto-politics." Public policies had to be agreed upon collectively; as a result elites had to co-opt or use material rewards to "buy off" underlings (Janos 2000, p. 260-263).

Moreover, labor exploitation and terror (particularly during the Stalinist regime) were random and defied pre-established legal norms and procedures. In Russia in the 1930s, being absent from work brought about the loss of the equivalent of six months' salary. In 1932, the punishment was increased to include the loss of living quarters and ration cards. Petty theft was punishable by ten years' imprisonment, and grand theft led to the death penalty. As of June 1940, those late for work for more than twenty minutes were subject to compulsory labor, while unauthorized employment change was punished by imprisonment or labor camp. As a consequence of these stringent regulations, the number of labor camp detainees reached 
six million in the 1930s and as many as fourteen million in the post-war period (Janos 2000, p. 224-225). During the Stalin era, 80,000 were detained in Czechoslovakia, 200,000 in Poland and 240,000 in East Germany. Just in 1950-1953 in Hungary, 511,270 people were arrested, leading to 387,177 sentences (Janos 2000, p. 252).

Third, communist policies sought to keep the population subservient and discouraged the questioning of authorities. Totalitarian countries were led by a single Marxist-Leninist party which also assumed most (or all) responsibilities of the state. The state and the Party controlled the daily lives (and thoughts) of the population and all aspects of the economy. In addition, civil society was limited and the state engaged in extensive propaganda which glorified communism and condemned capitalism (Pop-Eleches and Tucker 2017). There existed, however, a number of mass organizations - such as trade unions and youth organizations which were aimed at transmitting and solidifying communist ideas among the population (Janos 2000, p. 252). The secret police was essential for the survival of communist regimes. Uniformed and nonuniformed constables numbered 100,000 in Poland, 70,000 in Romania, 60,000 in Czechoslovakia, 50,000 in Hungary, 40,000 in Bulgaria, 25,000 in Yugoslavia and 80,000 in East Germany (Janos 2000, p. 254).

Finally, creativity, innovation and the flow of new ideas were stifled. Internal and external migration was limited: for instance, as early as 1932 the Soviet Union introduced the internal passport system, which required official authorization for change of residence or employment (Janos 2000, p. 224). ${ }^{7}$ Across the communist region, cultural revolutions tried to inculcate socialist ideas, while at the same time aiming to suppress destructive ideas stemming from Western jazz or the Western standards of living (Janos 2000, p. 251). Abramitzky and Sin (2014) use book translations as a new measure of idea flows and compare translation patterns in former Communist countries before and after 1989. When Com-

\footnotetext{
${ }^{7}$ In some countries - including Yugoslavia, Hungary and Poland - internal and external migration was more relaxed, and travel outside of the communist bloc was also possible.
} 
munism collapsed, Western-to-Communist translations increased by a factor of four, while Communist-to-Communist translations decreased by a factor of two thirds. The greatest increase in Western-to-Communist translations was precisely in fields which were suppressed during communism - such as religion, while the smallest increase was in translations in exact science.

In sum, despite successful government efforts to eradicate church-going from everyday life, specific religious beliefs and mindsets persisted during communism, as did differences between Orthodoxy, and Catholicism and Protestantism. In addition, certain cultural attributes of Eastern Orthodoxy thrived throughout the communist period. Communist governments pursued additional policies which fostered Orthodox values such as communitarianism, antilegalism, non-questioning of authorities, and the lack of creativity and innovation.

\section{Data}

\subsection{World Values Survey}

Our main data source are the last four waves of the World Values Survey, organized in a longitudinal data set, which jointly cover the period 1995-2014. We omit the first two waves of the survey (1981-1984, and 1990-1994), since they included a very small number of countries in which Eastern Orthodoxy is the prevalent religion. ${ }^{8}$ The World Values Survey consists of nationally representative surveys conducted in almost 100 countries which comprise nearly 90 per cent of the world's population, and includes interviews with more than 400,000 respondents. In table A1 in the online Appendix, we list the countries covered in the data set, along with information on the distribution of respondents identifying themselves as Eastern Orthodox, Catholic or Protestant. Although our sample includes a very diverse set of countries, we include country dummies in all specifications utilizing the World Values Survey

\footnotetext{
${ }^{8}$ Results do not change if these additional waves are included and are available from the authors.
} 
and therefore exploit only within-country variation. Table A1 presents information on the share of respondents belonging to the Eastern Orthodox, Catholic or Protestant religions, by country.

The target population of respondents consists of all adults aged 18 and over. The minimum sample is 1,000 . In most countries, some form of stratified multistage random probability sampling was used to obtain representative national samples. In the first stage, a random selection of primary sampling units, usually based on electoral districts or census enumeration units, is used. In most countries, the population size and degree of urbanity of the primary sampling units are also taken into account. In the second stage, individuals are selected randomly from each locality. Interviews are face-to-face, with the exception of remote areas.

\subsection{Life in Transition Survey}

As a complementary source, we also utilize two waves of the Life in Transition Survey (2010 and 2016). The Life in Transition Survey (LiTS) is a nationally representative survey which covers 29 post-communist countries. ${ }^{9}$ It was conducted by the European Bank for Reconstruction and Development and the World Bank in 2006, 2010 and 2016. Unfortunately, the 2006 wave of the survey only records whether the respondent is Christian, and does not distinguish among Catholicism, Orthodoxy and Protestantism. In 2010, the survey also included for comparison purposes five Western European countries (France, Germany, Italy, Sweden, United Kingdom) and Turkey. In 2016, it included Greece, Cyprus, Italy, Germany and Turkey. In table A2 in the online Appendix, we list the countries covered in the 2010 data set, along with information on the distribution of respondents identifying themselves

\footnotetext{
${ }^{9}$ These are Albania, Armenia, Azerbaijan, Belarus, Bosnia and Herzegovina, Bulgaria, Croatia, Czech Republic, Estonia, Georgia, Hungary, Kazakhstan, Kyrgyz Republic, Latvia, Lithuania, FYR Macedonia, Moldova, Mongolia, Poland, Romania, Russia, Serbia, Slovak Republic, Slovenia, Ukraine, Uzbekistan, Kosovo (2010 only) and Montenegro.
} 
as Eastern Orthodox, Catholic or Protestant.

Respondents (aged 18 and above) were drawn randomly, using a two-stage sampling method with primary and secondary sampling units. In 2006 and 2010, each country had a minimum of 50 primary sampling units with each primary sampling unit containing around 20 responding households (for a total of approximately 1,000 observations). In 2016, the number of primary sampling units was increased to 75 , for a total of approimately 1,500 observations per country.

The head of the household or another knowledgeable household member answered the Household Roster and questions about housing and expenses. All other modules ${ }^{10}$ were answered by a randomly drawn adult (over 18 years of age) from the household with no substitutions possible, using a minimum of three repeat visits if an interview could not be conducted. To keep results comparable with those of the World Values Survey, in the LiTS analyses we include country fixed effects only, though results are very similar if we instead include dummies for sub-national regions.

The major shortcoming of the LiTS is that, unlike the WVS, it contains a much smaller number of non-Orthodox countries. At the same time, it allows us to triangulate our hypotheses against a different data set.

\subsection{Dependent variables}

The attitudes which we explore are grouped in three broad categories:

- Religious behavior

To explore the link between Orthodoxy and religious behavior, we use the following information from the World Values Survey: (1) the frequency with which the respondent

\footnotetext{
${ }^{10}$ For instance, in the 2010 wave, the other modules are: Attitudes and Values; Climate Change; Labor, Education and Entrepreneurial Activity; Governance, and Miscellaneous Questions.
} 
attends religious services; (2) the frequency with which the respondent prays (both variables are on a scale of 1 (never) to 8 (always)); (3) a dummy variable for whether the respondent was raised religiously; (4) whether the respondent is a religious person (on a scale of 1 (atheist) to 3 (religious)); (5) a dummy variable for whether the respondent gets comfort and strength from religion; and (6) whether the respondent believes that we depend too much on science and not enough on faith (on a scale of 1 (completely disagree) to 10 (completely agree)).

- Happiness, social capital, risk attitudes and employment preferences

We make use of the following questions from the World Values Survey and the Life in Transition Survey: (1) the extent to which the respondent is satisfied with his/her life (on a scale of 1 (dissatisfied) to 4 (satisfied) in the WVS, while in the LiTS the scale is 1-10); (2) how many children the respondent has (ranging from 0 (no children) to 8 (8 or more children)); (3) the ideal number of children preferred by the respondent (ranging from 0 (no children) to 10 (10 or more children), WVS only); (4) the respondent's social capital, calculated as the average number of voluntary organizations (such as church or sports organizations) in which the respondent is an active member, ranging from 0 to 9 (WVS only); (5) whether the respondent usually votes in national elections (on a scale of 1 (never) to 3 (always), WVS only); and (6) the respondent's opinion about new versus old ideas, which is on a scale of 1 (Ideas that stood the test of time are generally best) to 10 (New ideas are generally better than old ones, WVS only).

We utilize the following questions from the LiTS only: (1) the size of the respondent's household (ranging from 1 person to 10 or more people); (2) the respondent's risk preference (ranging from 1 (not willing to take risks) to 10 (very much willing to take risks)); (3) a dummy which is 1 if the respondent prefers to work in a large private enterprise and 0 otherwise and (4) a dummy variable capturing whether the respondent prefers long-term 
job safety over opportunities for promotion and higher pay. The dummy variable is 1 if the respondent prefers job safety, lower pay and lower opportunities for promotion; and 0 if the respondent prefers higher pay and more opportunities for promotion at the expense of lower job security. ${ }^{11}$ Unfortunately, the last two questions (on employment preferences) were not asked in the 2016 LiTS.

- Opinions about government and society

We utilize solely the World Values Survey for these regressions, as the set of relevant questions in the LiTS is much smaller. We use the following questions: (1) the respondent's self-position on a left-right scale (on a scale of 1 (left) to 10 (right)); (2) the interviewee's opinion about private vs. state ownership of business (on a scale of 1 (private ownership should be increased) to 10 (government ownership should be increased)); (3) the respondent's opinion about government responsibility (on a scale of 1 (people should take more responsibility) to 10 (government should take more responsibility)); (4) a dummy for whether the respondent is willing to fight for his/her country (1 - yes, 0 - no); (5) the respondent's preference for democracy (on a scale of 1 (bad) to 4 (good)); and (6) the respondent's opinion about wealth accumulation (on a scale of 1: "People can only get rich at the expense of others" to 10: "Wealth can grow so that there is enough for everyone").

\subsection{Independent variables}

Our main independent variables of interest are dummies for the respondent's self-reported religious affiliation, which include Eastern Orthodoxy, Catholicism and Protestantism. We also include a dummy for other religious affiliation, which means that the coefficients on the religion dummies can be interpreted relative to the omitted category (non-religious respondents). Importantly, Eastern Orthodoxy does not include Oriental Orthodoxy, which is

\footnotetext{
${ }^{11} \mathrm{~A}$ similar question in WVS on whether the respondent values good job security was only asked in the 1999-2004 wave.
} 
prevalent in Armenia, Eritrea, Ethiopia, Egypt, Syria, Lebanon and India. ${ }^{12}$ We control for a variety of respondent-level characteristics, such as demographics, socio-economic status, education, parental education, whether the respondent or any members of his/her family were members of the communist party and whether the respondent resides in an urban locality.

\section{Empirical specification and results}

Our estimation strategy exploits religious variation within countries. For the World Values Survey, we run specifications of the following form:

$$
\begin{aligned}
& \text { Outcome }_{i c t}=\alpha_{i c t}+\beta_{1} \text { Orthodox }_{i c t}+\beta_{2} \text { Catholic }_{i c t}+\beta_{3} \text { Protestant }_{i c t}+\beta_{4} \text { OtherReligion }_{i c t}+ \\
& +\boldsymbol{X}_{\text {ict }} \beta_{5}+\gamma_{c}+\text { SurveyWave }_{t}+\gamma_{c} * \text { SurveyWave }_{t}+\epsilon_{i c t}
\end{aligned}
$$

Our specifications with the Life in Transition Survey parallel those with the World Values Survey described above. LiTS provides information on the parental background of the respondent. The downside is that the number of attitudinal questions asked in the LiTS is smaller than that in WVS, and the set of covered countries (particularly non-Orthodox ones) is much smaller. In addition, since LiTS 2010 and 2016 do not constitute an individual panel, we must rely solely on cross-sectional variation. ${ }^{13}$

For the LiTS, we run specifications of the following form:

\footnotetext{
${ }^{12}$ Oriental Orthodoxy is theologically distinct from Eastern Orthodoxy, and since we are interested in the relationship between Eastern Orthodoxy and communism, separating Eastern Orthodoxy and Oriental Orthodoxy is logical. However, the results are robust to coding Oriental Orthodoxy as part of Eastern Orthodoxy and are available from the authors.

${ }^{13}$ It is possible to build a panel of PSUs included in both surveys. However, inference based on such a panel is limited because of: (1) the small number of observations per PSU; (2) migration; and (3) the fact that the LiTS data are not representative at the sub-national level.
} 


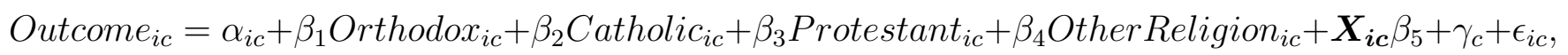

where for respondent $i$ in country $c$ and survey wave $t, O u t c o m e e_{i c(t)}$ is one of the measures of religious behavior, happiness, social capital, risk attitudes, employment preferences, and opinions about government and society described above. Orthodox $x_{i c(t)}$, Catholic $i_{i c(t)}$, Protestant $_{i c(t)}$ and OtherReligion $i c(t)$ are dummies for whether the respondent belongs to Eastern Orthodoxy, Catholicism, Protestantism or another religion. ${ }^{14}$ The omitted category is respondents who do not report following any religion.

$\boldsymbol{X}_{\boldsymbol{i c}(\boldsymbol{t})}$ is a vector of respondent-level controls. First, we include a dummy for whether the respondent is employed, which is 1 if the respondent is employed either full-time, parttime, or self-employed; and 0 if the respondent is retired, housewife, student, unemployed or with another employment status (WVS), or a dummy for whether the respondent has been employed in the past 12 months (LiTS). Second, we control for respondent's income, which is reported on a scale of 1 (lowest step) - 11 (highest step) (in the WVS) and on a scale of 1-10 (in the LiTS). Third, we account for each respondent's self-reported health status, on a scale of 1 (very poor) to 5 (very good). We also include dummies for whether the interviewee completed secondary, and university education and above (with the omitted category primary education and lower). Controls for the respondent's sex, age (along with age squared) and marital status are also included. Finally, we include a variable which measures the size of the town in which the respondent lives, which ranges from $1(2,000$ inhabitants or less) to 8 (500,000 inhabitants or more) (in the WVS only), while in the LiTS this variable is a dummy for whether the respondent lives in an urban area. The LiTS specifications include two additional control variables: (1) respondent's father's years of full-

\footnotetext{
${ }^{14}$ In the LiTS, the Protestant category also includes all other Christian denominations.
} 
time education, and (2) a dummy for whether the respondent, or any members of his family, were part of the former communist party. The regressions include country dummies $\left(\gamma_{c}\right)$, survey wave dummies (SurveyWave $_{t}$ (WVS only), and an interaction between country and survey wave dummies $\left(\gamma_{c} * \text { SurveyWave }\right)_{t}$ (WVS only). Standard errors are clustered at the country level. Survey weights, which ensure that the data are representative at the national level, are included in all specifications.

\subsection{Results}

In Table 1, we first test if self-reported religious affiliation has a differential effect on various aspects of religious behavior. All the regressions in this table use the World Values Survey. In column (1), the dependent variable is the frequency with which the respondent attends religious services, while in column (2) we look at how often the respondent prays. In both cases, the effect of self-reported religious affiliation is strongly significant and very similar among respondents who are Orthodox, Catholic, Protestant or of other religious affiliation, relative to the omitted category. The pattern is very similar in the next four columns, in which we investigate the effect of religious affiliation on whether the interviewee reports to have been raised religiously, whether he or she self-qualifies as a religious person, whether the respondent finds comfort and strength in religion, and whether he or she believes that

we depend too much on science and not on faith (columns (3)-(6)). Those who are married, and those who reside in smaller towns exhibit a stronger attachment to religion (the latter two coefficients are not reported in the table to conserve space). There are also negative effects of higher income and educational attainment, though the estimates are less robust across specifications.

[Table 1 here]

In Table 2, we study how belonging to different Christian faiths affects happiness and 
social capital, using data from the World Values Survey. Column (1) shows that respondents who are Catholic and Protestant are approximately 0.03 points happier compared to non-religious respondents, which is between $1.1-1.2 \%$ relative to the mean of the dependent variable (3.07). ${ }^{15}$ In contrast, Orthodox respondents are not different from the non-religious group. In column (2) we find that those of Orthodox religion have fewer children compared to Catholics, Protestants, respondents belonging to other religions and the omitted category, and the magnitude of the effect is $4.7 \%$ relative to the mean of the dependent variable. Column (3) demonstrates that the ideal number of children is the same for Orthodox and Protestant believers and the non-religious. At least for Protestants, these results are consistent with the idea that they may opt to have more children not because they have different preferences, but because they are more satisfied with their lives as compared to those of Orthodox faith or those who do not follow a religion.

Column (4) shows that Orthodox respondents have more social capital than non-believers, but the Orthodox coefficient is significantly lower compared to that for Catholicism, Protestantism and other religions. ${ }^{16}$ Interestingly, we find little evidence that Catholics and Protestants are more active voters relative to Eastern Orthodox believers and non-religious respondents (column 5), as the coefficients on the three Christian denominations are not statistically different from each other. Finally, column (6) confirms that Eastern Orthodoxy is associated with stronger attachment to tradition: Orthodox individuals are 0.222 points less likely to support new ideas, which is $4.2 \%$ relative to the mean of the dependent variable.

\section{[Table 2 here]}

In Table 3, we run additional regressions probing into the differences in happiness, risk attitudes and employment preferences among the three Christian denominations. These

\footnotetext{
${ }^{15}$ The F-statistic from a test of equality of coefficients between Orthodoxy and Catholicism is 7.04 with a p-value of 0.0096 . We clarify when the Orthodox coefficient is not different from the Catholic/Protestant coefficients in the subsequent regressions.

${ }^{16}$ The F-statistic from a test of equality of coefficients between Orthodoxy and Catholicism (representing the most conservative test in this case) is 27.28 with a p-value of 0.0000 .
} 
specifications rely solely on cross-sectional variation from the 2010 round of the Life in Transition Survey. Unlike the previous two tables, Table 3 controls for parental background, including respondent's father's years of full-time education and whether the respondent, or anyone from his/her family were members of the former communist party. The results in column (1) are actually stronger compared to those in column (1) in Table 2 - Catholics are approximately $4.0 \%$ happier and Protestants are 5.8\% happier relative to Orthodox believers and non-believers (both effects are calculated using the mean of the happiness variable). Those of Catholic and Protestant faith live in households which have more children (though the effect is imprecisely estimated) and are bigger in size (note that the Protestant coefficient is not statistically different from the Orthodox one, columns (2) and (3)). Orthodox believers are less likely to take risks (relative to Catholics, Protestants and non-believers, column (4)) and are less likely to prefer employment in a large private enterprise (relative to Protestants and non-believers, column (5)). Orthodox believers are 8.8 percentage points more likely to prefer a safe job relative to non-believers, while this effect is 4.5 percentage points for Catholics and 3.8 percentage points for Protestants, respectively (column 6). ${ }^{17}$ These results echo the earlier findings on the differences between Catholicism and Protestantism, and Orthodoxy when it comes to social capital and support for new ideas.

[Table 3 here]

One concern about the results in Table 3 is that they could be driven by the fact that LiTS II was fielded at the height of the financial crisis. To check this, we rerun the analysis in the previous table using data from LiTS III. Unfortunately, questions about employment preferences were not included in the latest round of the survey. The results in Table 4 are broadly similar to those in Table 3, though the four religious groups and non-believers do not appear to be different in terms of happiness (column (1)). Orthodox believers have

\footnotetext{
${ }^{17}$ The Orthodox coefficient is statistically different from the Catholic and Protestant ones, with p-values of 0.0157 and 0.0124 , respectively.
} 
fewer children, live in smaller households and are less risk-loving (though the coefficients on the three religious denominations are not statistically different in the latter specification), as compared to non-believers and Catholics, Protestants and members of other religions (columns $(2)-(4))$.

[Table 4 here]

Finally, Table 5 documents how differences among the three Christian denominations affect opinions about government and society, once again focusing on the World Values Survey. Column (1) shows that Catholics and Protestants are more likely to report right-leaning political preferences, where the difference with non-believers ranges between 0.456 and 0.539 points (on a scale of 1 (left) to 10 (right)). As a comparison, Orthodox adherents position themselves only 0.127 points more to the right relative to non-believers. ${ }^{18}$ Catholics and Protestants are less supportive of government responsibility and government ownership, as compared to both non-believers and those of Orthodox faith (columns (2) - (3)). Interestingly, we find no differences when it comes to willingness to fight for one's country or preferences for democracy in columns (4) and (5), as the Orthodox coefficient is not statistically different from those on Catholicism or Protestantism.

The results in Table 5 also suggest that adherents of Orthodoxy and Protestantism have different views on wealth accumulation, which are consistent with the theological differences relating to individualism and communitarianism discussed above. Protestants are more likely to agree that wealth can grow so that there is enough for everyone, compared to Orthodox adherents (column (6); the Orthodox coefficient is not statistically different from the Catholic coefficient). Protestants view individual wealth accumulation (and the associated rewards that can be enjoyed before death) as acceptable, while the opinions of Orthodox adherents

\footnotetext{
${ }^{18}$ These differences are statistically significant. The coefficients on Catholicism and Protestantism are not different from each other, while the test of equality of coefficients between Orthodoxy and Catholicism is rejected with an F-statistic of 22.49 and a p-value of 0.000 . Equality of coefficients is also rejected when the Orthodox coefficient is compared to that of Protestantism.
} 
would be consistent with a worldview in which individual enrichment is eschewed so that communal well-being is maximized.

[Table 5 here]

Consistent with the discussion in Section 2, the results in Tables 2 - 5 suggest that there are strong cultural differences among Eastern Orthodox, Catholic and Protestant adherents. Relative to those belonging to the Catholic or Protestant religion (and non-believers), Eastern Orthodox respondents have fewer children, less social capital and are more risk-averse. They also prefer old, rather than new, ideas and safe jobs, are more left-leaning and stronger government supporters.

What is more, Catholics and Protestants have distinct attitudes and values as well. Relative to non-believers and those professing Orthodoxy, they are happier and less likely to agree that government ownership is a good thing. In addition, Protestants (but not Catholis) are less likely to agree that getting rich can only happen at the expense of others.

Finally, we also ran specifications with additional dependent variables, including the extent to which the respondent trusts various institutions, such as political institutions and banks, along with preferences for market economy and democracy (available from the LiTS) and the degree to which the respondent respects authority (available from the WVS). We do not find any significant differences between Orthodoxy, and Catholicism and Protestantism, in these specifications. While these results are inconsistent with the hypotheses advanced in this paper, we believe that the wide array of attitudes and values for which we do find important differences among the three religious denominations are quite interesting and provide strong support for our theoretical priors. ${ }^{19}$

\footnotetext{
${ }^{19}$ These results are available from the authors. Please note that we did not apply the Bonferroni correction to these analyses as research has shown that such an approach may be problematic (Nakagawa 2004).
} 


\section{Conclusion}

In this paper, we study how deep-rooted theological differences between Orthodoxy, and Catholicism and Protestantism, affect life satisfaction and other attitudes and values in large parts of Europe today. Using four waves of the World Values Survey and the 2010 and 2016 rounds of the Life in Transition Survey, we find that, relative to Orthodox adherents and non-believers, Catholics and Protestants are happier, have more children and are less likely to agree that government ownership is a good thing. Protestants are also less likely to agree that getting rich can only happen at the expense of others. Consistent with the happiness results, we find that relative to Catholics, Protestants and non-believers, those of Eastern Orthodox religion have less social capital and are more risk-averse. They also prefer old, rather than new, ideas and safe jobs. Orthodox believers have more left-leaning political orientations and a stronger opinion that governments (versus people) should take more responsibility.

An important question is how exactly these attitudinal differences persisted throughout time, particularly given the strict anti-religious policies adopted by communist elites. One part of the explanation is that religious differences and beliefs are particularly resilient. They were able to resist not only fifty years of communist suppression, but also many centuries of political and economic upheaval beforehand. In addition, although totalitarian governments suppressed religious activities, they preserved those aspects of Orthodox religion - such as tradition and communitarianism - which were helpful for advancing the communist doctrine.

Our findings have important implications for understanding the determinants of the economic and political transformation in Eastern Europe. A large literature has argued that the totalitarian legacy has affected profoundly the cultural, economic and political landscape of the post-communist region (Pop-Eleches and Tucker 2017). While influential, such views may be only partially complete. This paper points out that theological differences among 
different Christian denominations may have set countries on different development paths long before the arrival of communism and that communist elites may have exploited cultural environments to their own benefit. We must also clarify that we do not claim to provide a "one-size-fits-all" theory of cultural and economic change. There are many forces that shape political and economic development and religion is only one of them.

As pointed out in the introduction, the debate on the pre-conditions conducive to the emergence of different types of political and economic systems is not new. Communist thinkers themselves disagreed on where communism would be most successful. In hindsight, it seems that neither Marx's idea that socialism was most likely to take root in advanced countries, nor Lenin's belief that Orthodoxy must be eradicated completely among the lower classes for communism to succeed were correct. Instead, communist ideology and ideas flourished precisely in poorer countries with a strong Eastern Orthodox tradition. These findings provide strong support for Berdyaev's theory that "the social system of communism ... can be wholly reconciled with [Orthodox] Christianity, more so, in any case, than the capitalist system" (Berdyaev 1937, p. 184). 


\section{References}

Abramitzky, R. And I. Sin (2014): "Book translations as idea flows: The effects of the collapse of Communism on the diffusion of knowledge," Journal of the European Economic Association, 12, 1453-1520.

Acemoglu, D., S. Johnson, And J. A. Robinson (2001): "The Colonial Origins of Comparative Development: An Empirical Investigation," American Economic Review, 91, 1369-1401.

Adena, M., R. Enikolopov, M. Petrova, V. Santarosa, and E. Zhuravskaya (2015): "Radio and the Rise of the Nazis in Prewar Germany," Quarterly Journal of Economics, 130, 1885-1939.

Aghion, P., Y. Algan, P. Cahuc, And A. Shleifer (2010): "Regulation and distrust," The Quarterly Journal of Economics, 125, 1015-1049.

AidT, T. S. AND R. FRANCK (2015): "Democratization under the threat of revolution: evidence from the great reform act of 1832," Econometrica, 83, 505-547.

Alesina, A. And N. Fuchs-Schündeln (2007): "Good-Bye Lenin (or Not?): The Effect of Communism on People's Preferences," American Economic Review, 97, 1507-1528.

Barmenkov, A. (1983): Freedom of Conscience in the USSR, Progress Publishers.

Barro, R. J. And R. M. MCCleary (2003): "Religion and Economic Growth across Countries," American Sociological Review, 760-781.

Becker, S. O., K. Boeckh, C. Hainz, and L. Woessmann (2014): "The Empire Is Dead, Long Live the Empire! Long-Run Persistence of Trust and Corruption in the Bureaucracy," Economic Journal.

Becker, S. O. And L. Woessmann (2009): "Was Weber wrong? A human capital theory of Protestant economic history," The Quarterly Journal of Economics, 531-596.

BÉnabou, R., D. Ticchi, And A. Vindigni (2015): "Religion and innovation," American Economic Review, 105, 346-351.

Berdyaev, N. (1933): "The End of Our Time," Donald Atwater (London: Sheed E Ward, 1933).

(1937): The origin of Russian communism, University Press Glasgow.

Boix, C. (2003): Democracy and Redistribution, Cambridge University Press.

(2011): "Democracy, Development, and the International System," American Political Science Review, 105, 809-28. 
Campante, F. And D. Yanagizawa-Drott (2015): "Does Religion Affect Economic Growth and Happiness? Evidence from Ramadan," Quarterly Journal of Economics, 130, 615-658.

Cantoni, D. (2014): "The economic effects of the Protestant Reformation: testing the Weber hypothesis in the German Lands," Journal of the European Economic Association.

Chambers, D. (2006): Popes, Cardinals and War: The Military Curch in Renaissance and Early Modern Europe, IB Tauris.

Chong, A., R. La Porta, F. Lopez-de Silanes, And A. Shleifer (2014): "Letter grading government efficiency," Journal of the European Economic Association, 12, 277299.

Clingingsmith, D., A. I. Khwaja, And M. Kremer (2009): "Estimating the Impact of The Hajj: Religion and Tolerance in Islam's Global Gathering," Quarterly Journal of Economics, 124, 1133-1170.

Coupe, T. And M. Obrizan (2016): "The impact of war on happiness: The case of Ukraine," Journal of Economic Behavior $\&$ Organization, 132, 228-242.

Djankov, S., E. Glaeser, R. La Porta, F. Lopez-de Silanes, and A. Shleifer (2003): "The new comparative economics," Journal of Comparative Economics, 31, 595619.

Djankov, S., E. Nikolova, And J. Zilinsky (2016): "The happiness gap in Eastern Europe," Journal of Comparative Economics, 44, 108-124.

Du BoIs, W. E. B. (1968): The autobiography of WEB Du Bois: A soliloquy on viewing my life from the last decade of its first century, Oxford University Press.

EAsterlin, R. A. (2009): "Lost in transition: Life satisfaction on the road to capitalism," Journal of Economic Behavior \& Organization, 71, 130-145.

Engerman, S. L. And K. L. Sokoloff (2000): "History Lessons: Institutions, Factors Endowments, and Paths of Development in the New World," Journal of Economic Perspectives, 14, 217-232.

Flora, G. AND G. SzIlagyi (2005): "Orthodox Christianity, Rationalization, Modernization: A Reassesment," in Eastern Orthodoxy in a Global Age: Tradition Faces the Twenty-first Century, ed. by V. Roudometoff, A. Agadjanian, and J. Pankhurst, Walnut Creek: Rowman \& Littlefield, chap. 5, 109-143.

Froese, P. (2001): "Hungary for religion: A Supply-side interpretation of the Hungarian religious revival," Journal for the Scientific Study of Religion, 40, 251-268. 
(2004): "Forced secularization in Soviet Russia: Why an atheistic monopoly failedForced secularization in Soviet Russia: Why an atheistic monopoly failed," Journal for the Scientific Study of Religion, 43, 35-50.

Froese, P. And S. Pfaff (2001): "Replete and desolate markets: Poland, East Germany, and the new religious paradigm," Social Forces, 80, 481-507.

Gorodnichenko, Y. And G. Roland (2015): "Culture, institutions and democratization," National Bureau of Economic Research.

Guiso, L., P. Sapienza, And L. Zingales (2003): "People's opium? Religion and economic attitudes," Journal of Monetary Economics, 50, 225-282.

Huntington, S. P. (1996): The clash of civilizations and the remaking of world order, Simon and Schuster.

Hussey, J. M. (2010): The orthodox church in the Byzantine empire, OUP Oxford.

Janos, A. C. (2000): East Central Europe in the modern world: the politics of the borderlands from pre-to postcommunism, Stanford University Press.

Kallistos, B. o. D. (1993): The orthodox church, Penguin UK.

La Porta, R., F. Lopez-de Silanes, A. Shleifer, And R. Vishny (1999): "The quality of government," Journal of Law, Economics, and organization, 15, 222-279.

La Porta, R., F. Lopez-de Silanes, A. Shleifer, and R. W. Vishny (1997): "Trust in Large Organizations," American Economic Review, 333-338.

LAL, D. (2000): "Does modernization require westernization?" Independent ReviewOakland, 5, 5-24.

Lenin, V. I. (1960): "Collected Works. 45 vols," Moscow, 70, 99-100.

Markides, V. N. (2005): "Orthodox Christianity, Rationalization, Modernization: A Reassesment," in Eastern Orthodoxy in a Global Age: Tradition Faces the Twenty-first Century, ed. by V. Roudometoff, A. Agadjanian, and J. Pankhurst, Walnut Creek: Rowman \& Littlefield, chap. 7, 179-209.

Marx, K. (1844): "Contribution to the Critique of Hegels Philosophy of Law," Collected works, 3, 3-129.

(1977): A contribution to the critique of political economy, Progress Publishers, Moscow.

McCleary, R. M. and R. J. Barro (2006): "Religion and economy," Journal of Economic Perspectives, 49-72. 
Metodiev, M. (2012): "Texts about communism in Bulgaria: the Bulgarian Orthodox church and the communist state," Konrad Adenauer Stiftung, 1-20.

NAKAGaWA, S. (2004): "A farewell to Bonferroni: the problems of low statistical power and publication bias," Behavioral ecology, 15, 1044-1045.

Nikolova, E. (2017): "Destined for democracy? Labor markets and political change in colonial British America," British Journal of Political Science, 47, 19-45.

Nikolova, M. (2016): "Minding the happiness gap: Political institutions and perceived quality of life in transition," European Journal of Political Economy, 45, 129-148.

Nunn, N. And L. Wantchekon (2011): "The Slave Trade and the Origins of Mistrust in Africa," American Economic Review, 101, 3221-3252.

PIPES, R. (1995): Russia Under the Bolshevik Regime, Vintage.

Pop-Eleches, G. And J. Tucker (2017): Communisms Shadow: Historical Legacies, and Political Values and Behavior, Princeton University Press.

Pospielovsky, D. (1984): The Russian church under the soviet regime, 1917-1982, vol. 1, St. Vladimir's Seminary Press.

- (1987): A History of Marxist-Leninist Atheism and Soviet anti-religious policies, vol. 1, Macmillan Press.

Roland, G. (2004): "Understanding institutional change: fast-moving and slow-moving institutions," Studies in Comparative International Development, 38, 109-131.

Spenkuch, J. L. (2011): "The Protestant Ethic and Work: Micro Evidence from Contemporary Germany," Working paper.

Stan, L. And L. Turcescu (2000): "The Romanian Orthodox Church and postcommunist democratisation," Europe-Asia Studies, 52, 1467-1488.

Stulz, R. M. And R. Williamson (2003): "Culture, openness, and finance," Journal of Financial Economics, 70, 313-349.

Tabellini, G. (2010): "Culture and institutions: economic development in the regions of Europe," Journal of the European Economic Association, 8, 677-716.

Tönnes, B. (1982): "Religious persecution in Albania," Religion, State and Society: The Keston Journal, 10, 242-255.

Volkov, D. (2005): "Living Eastern Orthodox Religion in the United States," in Eastern Orthodoxy in a Global Age: Tradition Faces the Twenty-first Century, ed. by V. Roudometoff, A. Agadjanian, and J. Pankhurst, Walnut Creek: Rowman \& Littlefield, chap. 9, 224-244. 
Weber, M. (1904): The Protestant Ethic and the Spirit of Capitalism: and other writings, Archiv fr Sozialwissenschaft und Sozialpolitik.

Winter, S. F. (1998): "Quo Vadis? The Roman Catholic Church in the Czech Republic," Religion, State and Society: The Keston Journal, 26, 217-233. 


\section{FIGURES AND TABLES}


Table 1: Self-reported religion matters - World Values Survey

\begin{tabular}{|c|c|c|c|c|c|c|}
\hline & $\begin{array}{c}(1) \\
\text { Attend relig. serv }\end{array}$ & $\begin{array}{c}(2) \\
\text { Prayer }\end{array}$ & $\begin{array}{c}(3) \\
\text { Raised religiously }\end{array}$ & $\begin{array}{l}(4) \\
\text { Religious person }\end{array}$ & $\begin{array}{c}(5) \\
\text { Comfort/strength from religion }\end{array}$ & $\begin{array}{c}(6) \\
\text { Science vs. faith }\end{array}$ \\
\hline orthodox & $\begin{array}{l}2.103^{* * *} \\
(0.142)\end{array}$ & $\begin{array}{l}2.181^{* * *} \\
(0.177)\end{array}$ & $\begin{array}{l}0.235^{* * *} \\
(0.024)\end{array}$ & $\begin{array}{l}0.605^{* * *} \\
(0.032)\end{array}$ & $\begin{array}{l}0.320^{* * *} \\
(0.050)\end{array}$ & $\begin{array}{l}0.709^{* * *} \\
(0.131)\end{array}$ \\
\hline catholic & $\begin{array}{l}2.344^{* * *} \\
(0.096)\end{array}$ & $\begin{array}{l}2.003^{* * *} \\
(0.205)\end{array}$ & $\begin{array}{l}0.366^{* * *} \\
(0.045)\end{array}$ & $\begin{array}{l}0.601^{* * *} \\
(0.043)\end{array}$ & $\begin{array}{l}0.390^{* * *} \\
(0.028)\end{array}$ & $\begin{array}{l}0.619^{* * *} \\
(0.132)\end{array}$ \\
\hline protestant & $\begin{array}{l}2.465^{* * *} \\
(0.169)\end{array}$ & $\begin{array}{l}2.157^{* * *} \\
(0.264)\end{array}$ & $\begin{array}{l}0.231^{* * *} \\
(0.042)\end{array}$ & $\begin{array}{l}0.569^{* * *} \\
(0.042)\end{array}$ & $\begin{array}{l}0.373^{* * *} \\
(0.033)\end{array}$ & $\begin{array}{l}0.561^{* * *} \\
(0.167)\end{array}$ \\
\hline other religion & $\begin{array}{l}2.217^{* * *} \\
(0.173)\end{array}$ & $\begin{array}{l}2.178^{* * *} \\
(0.204)\end{array}$ & $\begin{array}{l}0.314^{* * *} \\
(0.038)\end{array}$ & $\begin{array}{l}0.570^{* * *} \\
(0.042)\end{array}$ & $\begin{array}{l}0.367^{* * *} \\
(0.049)\end{array}$ & $\begin{array}{l}0.678^{* * *} \\
(0.155)\end{array}$ \\
\hline employed & $\begin{array}{c}0.049 \\
(0.039)\end{array}$ & $\begin{array}{c}0.052 \\
(0.048)\end{array}$ & $\begin{array}{l}-0.015^{* *} \\
(0.006)\end{array}$ & $\begin{array}{c}-0.001 \\
(0.004)\end{array}$ & $\begin{array}{c}-0.007 \\
(0.005)\end{array}$ & $\begin{array}{c}0.046^{*} \\
(0.023)\end{array}$ \\
\hline income & $\begin{array}{c}-0.007 \\
(0.006)\end{array}$ & $\begin{array}{c}-0.024^{* *} \\
(0.009)\end{array}$ & $\begin{array}{c}-0.000 \\
(0.002)\end{array}$ & $\begin{array}{c}-0.001 \\
(0.002)\end{array}$ & $\begin{array}{l}-0.006^{* * *} \\
(0.001)\end{array}$ & $\begin{array}{c}0.004 \\
(0.013)\end{array}$ \\
\hline male & $\begin{array}{c}-0.141 \\
(0.087)\end{array}$ & $\begin{array}{l}-0.444^{* * *} \\
(0.083)\end{array}$ & $\begin{array}{l}-0.035^{* * *} \\
(0.005)\end{array}$ & $\begin{array}{l}-0.083^{* * *} \\
(0.007)\end{array}$ & $\begin{array}{l}-0.071^{* * *} \\
(0.008)\end{array}$ & $\begin{array}{l}-0.131^{* * *} \\
(0.037)\end{array}$ \\
\hline health & $\begin{array}{l}0.060^{* * *} \\
(0.013)\end{array}$ & $\begin{array}{c}0.009 \\
(0.021)\end{array}$ & $\begin{array}{c}-0.003 \\
(0.004)\end{array}$ & $\begin{array}{c}0.005 \\
(0.004)\end{array}$ & $\begin{array}{c}0.003 \\
(0.005)\end{array}$ & $\begin{array}{c}-0.054^{* *} \\
(0.023)\end{array}$ \\
\hline secondary & $\begin{array}{c}-0.080^{* *} \\
(0.038)\end{array}$ & $\begin{array}{l}0.029 \\
(0.050)\end{array}$ & $\begin{array}{c}-0.008 \\
(0.016)\end{array}$ & $\begin{array}{l}-0.027^{* * *} \\
(0.007)\end{array}$ & $\begin{array}{l}-0.030^{* * *} \\
(0.009)\end{array}$ & $\begin{array}{c}0.047 \\
(0.052)\end{array}$ \\
\hline university & $\begin{array}{l}0.026 \\
(0.048)\end{array}$ & $\begin{array}{c}0.131^{*} \\
(0.068)\end{array}$ & $\begin{array}{c}0.005 \\
(0.023)\end{array}$ & $\begin{array}{l}-0.044^{* * *} \\
(0.009)\end{array}$ & $\begin{array}{l}-0.043^{* * *} \\
(0.011)\end{array}$ & $\begin{array}{c}-0.030 \\
(0.079)\end{array}$ \\
\hline Country dummies & $\checkmark$ & $\checkmark$ & $\checkmark$ & $\checkmark$ & $\checkmark$ & $\checkmark$ \\
\hline Country/wave dummies & $\checkmark$ & $\checkmark$ & $\checkmark$ & $\checkmark$ & $\checkmark$ & $\checkmark$ \\
\hline Wave dummies & $\checkmark$ & $\checkmark$ & $\checkmark$ & $\checkmark$ & $\checkmark$ & $\checkmark$ \\
\hline Demog. controls & $\checkmark$ & $\checkmark$ & $\checkmark$ & $\checkmark$ & $\checkmark$ & $\checkmark$ \\
\hline $\begin{array}{l}\text { R-sq } \\
\text { Number of observations }\end{array}$ & $\begin{array}{r}0.383 \\
165156.000\end{array}$ & $\begin{array}{r}0.473 \\
55244.000\end{array}$ & $\begin{array}{r}0.334 \\
38674.000\end{array}$ & $\begin{array}{r}0.325 \\
162487.000\end{array}$ & $\begin{array}{r}0.312 \\
58945.000\end{array}$ & $\begin{array}{r}0.137 \\
92260.000\end{array}$ \\
\hline
\end{tabular}

Notes: OLS - Coefficients are reported. Country clustered standard errors in parentheses. Demographic controls include age, age squared, whether the respondent is married and urban residency. The dependent variables are the frequency with which the respondent attends religious services, the frequency with which the respondent prays, whether the respondent was raised religiously, whether the respondent is a religious person, whether the respondent gets comfort and strength from religion, and whether the respondent believes we depend too much on science and not on faith. Significance levels: $* p<0.1$, ** $p<0.05, * * * p<0.01$. 
Table 2: Happiness and social capital - World Values Survey

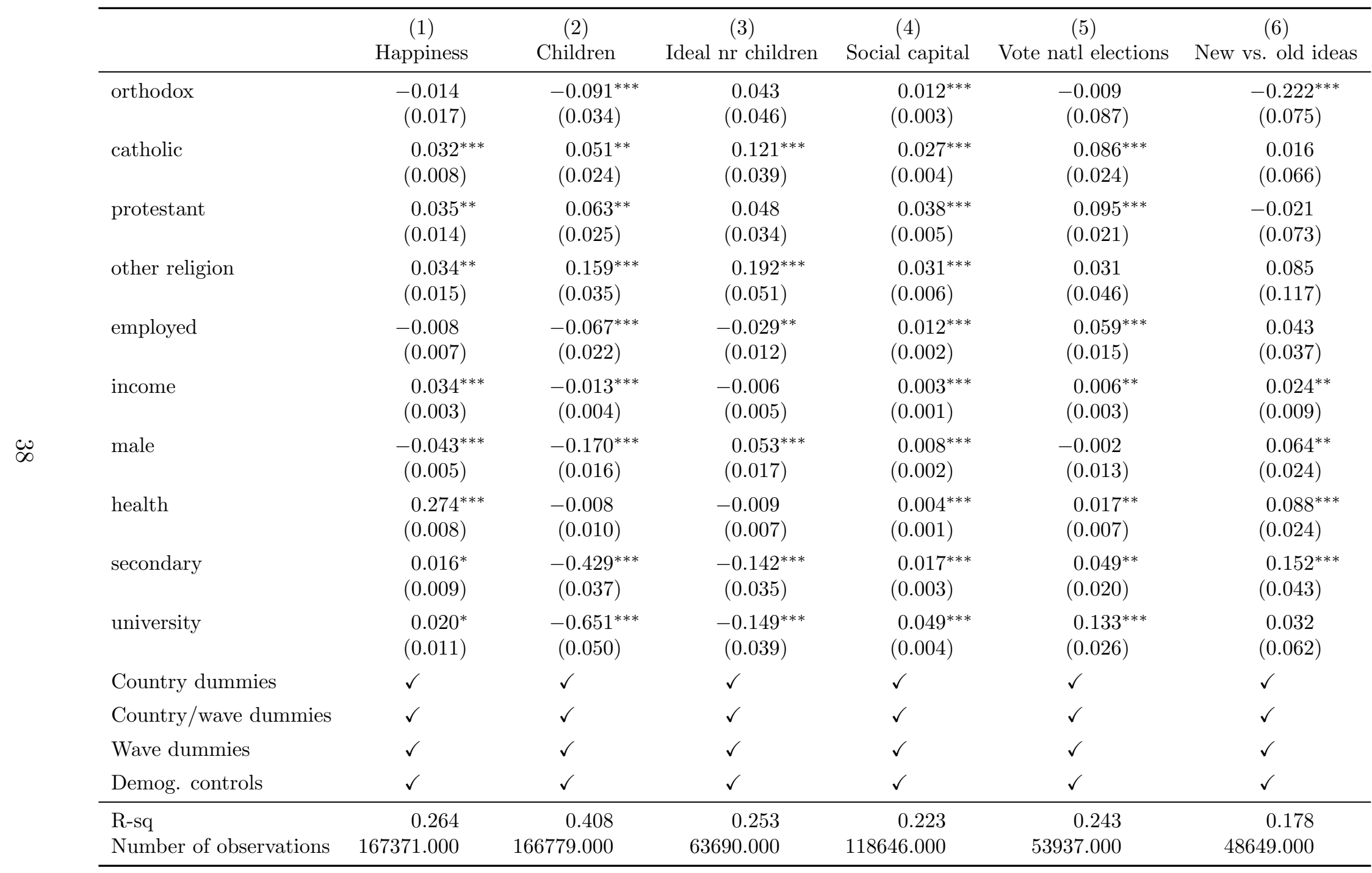

Notes: OLS - Coefficients are reported. Country clustered standard errors are in parentheses. Demographic controls include age, age squared, whether the respondent is married and urban residency. The dependent variables are happiness, how many children the respondent has, his/her ideal number of children, the respondent's social capital, whether the respondent usually votes in national elections, and whether he/she prefers new vs. old ideas. Significance levels: ${ }^{*} p<0.1,{ }^{* *} p<0.05,{ }^{* * *} p<0.01$. 
Table 3: Happiness, risk attitudes and employment preferences - Life in Transition Survey II

\begin{tabular}{|c|c|c|c|c|c|c|}
\hline & $\begin{array}{c}(1) \\
\text { Happiness }\end{array}$ & $\begin{array}{c}(2) \\
\text { Children }\end{array}$ & $\begin{array}{c}(3) \\
\text { Size of hh }\end{array}$ & $\begin{array}{l}(4) \\
\text { risk }\end{array}$ & $\begin{array}{c}(5) \\
\text { Prefer lg private ent. }\end{array}$ & $\begin{array}{c}(6) \\
\text { Prefer safe job }\end{array}$ \\
\hline orthodox & $\begin{array}{c}-0.093 \\
(0.070)\end{array}$ & $\begin{array}{c}-0.014 \\
(0.039)\end{array}$ & $\begin{array}{r}-0.018 \\
(0.069)\end{array}$ & $\begin{array}{l}-0.265^{* * *} \\
(0.093)\end{array}$ & $\begin{array}{c}-0.024^{* *} \\
(0.011)\end{array}$ & $\begin{array}{l}0.088^{* * *} \\
(0.020)\end{array}$ \\
\hline catholic & $\begin{array}{l}0.222^{* * *} \\
(0.072)\end{array}$ & $\begin{array}{c}0.060 \\
(0.038)\end{array}$ & $\begin{array}{l}0.110^{* *} \\
(0.047)\end{array}$ & $\begin{array}{l}-0.035 \\
(0.074)\end{array}$ & $\begin{array}{c}-0.015 \\
(0.014)\end{array}$ & $\begin{array}{l}0.045^{* * *} \\
(0.015)\end{array}$ \\
\hline protestant & $\begin{array}{l}0.318^{* * *} \\
(0.085)\end{array}$ & $\begin{array}{c}0.055 \\
(0.036)\end{array}$ & $\begin{array}{r}0.081^{*} \\
(0.046)\end{array}$ & $\begin{array}{c}0.001 \\
(0.086)\end{array}$ & $\begin{array}{c}0.004 \\
(0.016)\end{array}$ & $\begin{array}{l}0.038^{* *} \\
(0.016)\end{array}$ \\
\hline other religion & $\begin{array}{c}-0.113 \\
(0.077)\end{array}$ & $\begin{array}{l}0.173^{* * *} \\
(0.049)\end{array}$ & $\begin{array}{l}0.373^{* * *} \\
(0.090)\end{array}$ & $\begin{array}{c}-0.210^{* *} \\
(0.103)\end{array}$ & $\begin{array}{c}-0.012 \\
(0.012)\end{array}$ & $\begin{array}{l}0.056^{* *} \\
(0.021)\end{array}$ \\
\hline employed & $\begin{array}{c}0.072^{*} \\
(0.037)\end{array}$ & $\begin{array}{r}-0.027 \\
(0.025)\end{array}$ & $\begin{array}{c}-0.004 \\
(0.037)\end{array}$ & $\begin{array}{l}0.272^{* * *} \\
(0.045)\end{array}$ & $\begin{array}{c}0.010 \\
(0.007)\end{array}$ & $\begin{array}{c}-0.004 \\
(0.009)\end{array}$ \\
\hline Income, current & $\begin{array}{l}0.464^{* * *} \\
(0.027)\end{array}$ & $\begin{array}{l}-0.019^{* * *} \\
(0.006)\end{array}$ & $\begin{array}{c}0.005 \\
(0.011)\end{array}$ & $\begin{array}{l}0.193^{* * *} \\
(0.020)\end{array}$ & $\begin{array}{l}0.009^{* * *} \\
(0.002)\end{array}$ & $\begin{array}{c}-0.020^{* * *} \\
(0.003)\end{array}$ \\
\hline male & $\begin{array}{c}-0.088^{* *} \\
(0.037)\end{array}$ & $\begin{array}{c}-0.110^{* * *} \\
(0.016)\end{array}$ & $\begin{array}{c}0.035 \\
(0.032)\end{array}$ & $\begin{array}{l}0.637^{* * *} \\
(0.033)\end{array}$ & $\begin{array}{l}0.027^{\text {*** }} \\
(0.006)\end{array}$ & $\begin{array}{c}-0.074^{* * *} \\
(0.009)\end{array}$ \\
\hline father's education & $\begin{array}{l}0.020^{* * *} \\
(0.004)\end{array}$ & $\begin{array}{r}-0.004^{*} \\
(0.002)\end{array}$ & $\begin{array}{c}-0.012^{* * *} \\
(0.004)\end{array}$ & $\begin{array}{l}0.035^{* * *} \\
(0.008)\end{array}$ & $\begin{array}{l}0.002^{* *} \\
(0.001)\end{array}$ & $\begin{array}{c}-0.007^{* * *} \\
(0.001)\end{array}$ \\
\hline health & $\begin{array}{l}0.360^{* * *} \\
(0.028)\end{array}$ & $\begin{array}{c}0.022^{* *} \\
(0.009)\end{array}$ & $\begin{array}{c}0.029^{* *} \\
(0.014)\end{array}$ & $\begin{array}{l}0.196^{* * *} \\
(0.028)\end{array}$ & $\begin{array}{l}0.008^{* *} \\
(0.003)\end{array}$ & $\begin{array}{c}-0.021^{* * *} \\
(0.005)\end{array}$ \\
\hline communist & $\begin{array}{c}0.045 \\
(0.043)\end{array}$ & $\begin{array}{r}-0.028^{*} \\
(0.016)\end{array}$ & $\begin{array}{r}-0.001 \\
(0.025)\end{array}$ & $\begin{array}{r}-0.013 \\
(0.061)\end{array}$ & $\begin{array}{r}-0.010 \\
(0.007)\end{array}$ & $\begin{array}{c}0.013 \\
(0.009)\end{array}$ \\
\hline secondary & $\begin{array}{l}0.198^{* * *} \\
(0.045)\end{array}$ & $\begin{array}{c}-0.100^{* * *} \\
(0.034)\end{array}$ & $\begin{array}{r}-0.108^{*} \\
(0.056)\end{array}$ & $\begin{array}{l}0.315^{* * *} \\
(0.086)\end{array}$ & $\begin{array}{r}-0.012 \\
(0.009)\end{array}$ & $\begin{array}{c}-0.009 \\
(0.013)\end{array}$ \\
\hline university & $\begin{array}{l}0.412^{* * *} \\
(0.065)\end{array}$ & $\begin{array}{c}-0.184^{* * *} \\
(0.041)\end{array}$ & $\begin{array}{c}-0.266^{* * *} \\
(0.058)\end{array}$ & $\begin{array}{l}0.543^{* * *} \\
(0.084)\end{array}$ & $\begin{array}{c}-0.004 \\
(0.011)\end{array}$ & $\begin{array}{c}-0.075^{* * *} \\
(0.019)\end{array}$ \\
\hline Country dummies & $\checkmark$ & $\checkmark$ & $\checkmark$ & $\checkmark$ & $\checkmark$ & $\checkmark$ \\
\hline Demog. controls & $\checkmark$ & $\checkmark$ & $\checkmark$ & $\checkmark$ & $\checkmark$ & $\checkmark$ \\
\hline R-sq & 0.366 & 0.242 & 0.417 & 0.152 & 0.040 & 0.107 \\
\hline Number of observations & 26766.000 & 26769.000 & 26769.000 & 25976.000 & 24837.000 & 24956.000 \\
\hline
\end{tabular}

Notes: OLS - Coefficients are reported. Country clustered standard errors are in parentheses. Demographic controls include age, age squared, whether the respondent is married and urban residency. The dependent variables are happiness, how many children the respondent has, the size of the respondent's household, the respondent's willingness to takes risk, whether the respondent prefers employment in a large private enterprise, and whether the respondent prefers long-term job safety over opportunities for promotion and higher pay. Significance levels: ${ }^{*} p<0.1,{ }^{* *} p<0.05, * * * p<0.01$. 
Table 4: Happiness and risk attitudes - Life in Transition Survey III

\begin{tabular}{|c|c|c|c|c|}
\hline & $\begin{array}{c}(1) \\
\text { Happiness }\end{array}$ & $\begin{array}{l}(2) \\
\text { number of children }\end{array}$ & $\begin{array}{c}(3) \\
\text { size of } h h\end{array}$ & $\begin{array}{l}(4) \\
\text { risk }\end{array}$ \\
\hline orthodox & $\begin{array}{r}-0.011 \\
(0.050)\end{array}$ & $\begin{array}{c}-0.082^{* * *} \\
(0.029)\end{array}$ & $\begin{array}{l}-0.178^{* * *} \\
(0.057)\end{array}$ & $\begin{array}{c}-0.219^{* *} \\
(0.090)\end{array}$ \\
\hline catholic & $\begin{array}{c}0.071^{*} \\
(0.040)\end{array}$ & $\begin{array}{c}0.038^{*} \\
(0.020)\end{array}$ & $\begin{array}{c}0.076 \\
(0.045)\end{array}$ & $\begin{array}{r}-0.193 \\
(0.121)\end{array}$ \\
\hline protestant & $\begin{array}{c}0.028 \\
(0.038)\end{array}$ & $\begin{array}{r}-0.022 \\
(0.034)\end{array}$ & $\begin{array}{c}-0.054 \\
(0.062)\end{array}$ & $\begin{array}{c}-0.201 \\
(0.152)\end{array}$ \\
\hline other religion & $\begin{array}{c}0.006 \\
(0.062)\end{array}$ & $\begin{array}{c}0.068 \\
(0.049)\end{array}$ & $\begin{array}{c}0.168^{*} \\
(0.089)\end{array}$ & $\begin{array}{c}0.039 \\
(0.097)\end{array}$ \\
\hline employed & $\begin{array}{l}0.066^{* *} \\
(0.028)\end{array}$ & $\begin{array}{r}-0.039^{*} \\
(0.023)\end{array}$ & $\begin{array}{l}-0.006 \\
(0.034)\end{array}$ & $\begin{array}{l}0.399^{* * *} \\
(0.060)\end{array}$ \\
\hline Income, current & $\begin{array}{l}0.180^{* * *} \\
(0.012)\end{array}$ & $\begin{array}{c}-0.011^{* *} \\
(0.005)\end{array}$ & $\begin{array}{c}0.001 \\
(0.012)\end{array}$ & $\begin{array}{l}0.159^{* * *} \\
(0.026)\end{array}$ \\
\hline male & $\begin{array}{l}-0.059^{* * *} \\
(0.013)\end{array}$ & $\begin{array}{l}-0.049^{* * *} \\
(0.011)\end{array}$ & $\begin{array}{l}0.046^{* *} \\
(0.022)\end{array}$ & $\begin{array}{l}0.367^{* * *} \\
(0.042)\end{array}$ \\
\hline feduc & $\begin{array}{l}0.021^{* *} \\
(0.008)\end{array}$ & $\begin{array}{r}-0.011^{*} \\
(0.006)\end{array}$ & $\begin{array}{r}-0.022^{*} \\
(0.011)\end{array}$ & $\begin{array}{l}0.086^{* * *} \\
(0.018)\end{array}$ \\
\hline health & $\begin{array}{l}0.193^{* * *} \\
(0.016)\end{array}$ & $\begin{array}{r}0.018^{*} \\
(0.010)\end{array}$ & $\begin{array}{r}-0.002 \\
(0.024)\end{array}$ & $\begin{array}{l}0.193^{* * *} \\
(0.034)\end{array}$ \\
\hline communist & $\begin{array}{l}0.056^{* *} \\
(0.025)\end{array}$ & $\begin{array}{l}-0.004 \\
(0.014)\end{array}$ & $\begin{array}{c}0.018 \\
(0.026)\end{array}$ & $\begin{array}{l}0.172^{* * *} \\
(0.042)\end{array}$ \\
\hline secondary & $\begin{array}{c}0.002 \\
(0.015)\end{array}$ & $\begin{array}{c}0.019 \\
(0.021)\end{array}$ & $\begin{array}{l}0.075^{* *} \\
(0.035)\end{array}$ & $\begin{array}{r}-0.023 \\
(0.043)\end{array}$ \\
\hline university & $\begin{array}{l}0.125^{* * *} \\
(0.032)\end{array}$ & $\begin{array}{r}-0.012 \\
(0.026)\end{array}$ & $\begin{array}{c}-0.073 \\
(0.043)\end{array}$ & $\begin{array}{c}-0.040 \\
(0.068)\end{array}$ \\
\hline Country dummies & $\checkmark$ & $\checkmark$ & $\checkmark$ & $\checkmark$ \\
\hline Demog. controls & $\checkmark$ & $\checkmark$ & $\checkmark$ & $\checkmark$ \\
\hline $\begin{array}{l}\text { R-sq } \\
\text { Number of observations }\end{array}$ & $\begin{array}{r}0.255 \\
36922.000\end{array}$ & $\begin{array}{r}0.235 \\
37275.000\end{array}$ & $\begin{array}{r}0.355 \\
37275.000\end{array}$ & $\begin{array}{r}0.182 \\
36541.000\end{array}$ \\
\hline
\end{tabular}

Notes: OLS - Coefficients are reported. Country clustered standard errors are in parentheses. Demographic controls include age, age squared, whether the respondent is married and urban residency. See previous table for description of the dependent variables. Significance levels: * $p<0.1,{ }^{* *} p<0.05,{ }^{* * *} p<0.01$. 
Table 5: Opinions about government and society - World Values Survey

\begin{tabular}{|c|c|c|c|c|c|c|}
\hline & $\begin{array}{c}(1) \\
\text { Pol pref left right }\end{array}$ & $\begin{array}{l}(2) \\
\text { Govt own. }\end{array}$ & $\begin{array}{c}(3) \\
\text { Govt resp. }\end{array}$ & $\begin{array}{l}(4) \\
\text { Fight for country }\end{array}$ & $\begin{array}{l}(5) \\
\text { Preference for democracy }\end{array}$ & $\begin{array}{c}(6) \\
\text { Getting rich }\end{array}$ \\
\hline orthodox & $\begin{array}{l}0.127^{*} \\
(0.075)\end{array}$ & $\begin{array}{c}0.080 \\
(0.060)\end{array}$ & $\begin{array}{c}0.132^{*} \\
(0.075)\end{array}$ & $\begin{array}{c}0.019 \\
(0.020)\end{array}$ & $\begin{array}{c}0.030 \\
(0.019)\end{array}$ & $\begin{array}{c}0.009 \\
(0.080)\end{array}$ \\
\hline catholic & $\begin{array}{l}0.539^{* * *} \\
(0.050)\end{array}$ & $\begin{array}{l}-0.195^{* * *} \\
(0.056)\end{array}$ & $\begin{array}{c}-0.116^{* *} \\
(0.047)\end{array}$ & $\begin{array}{l}0.035^{* * *} \\
(0.012)\end{array}$ & $\begin{array}{l}0.031^{* *} \\
(0.014)\end{array}$ & $\begin{array}{l}0.132^{* * *} \\
(0.044)\end{array}$ \\
\hline protestant & $\begin{array}{l}0.456^{* * *} \\
(0.056)\end{array}$ & $\begin{array}{l}-0.263^{* * *} \\
(0.054)\end{array}$ & $\begin{array}{l}-0.181^{* * *} \\
(0.051)\end{array}$ & $\begin{array}{l}0.030^{* *} \\
(0.013)\end{array}$ & $\begin{array}{l}0.044^{* * *} \\
(0.016)\end{array}$ & $\begin{array}{l}0.170^{* * *} \\
(0.050)\end{array}$ \\
\hline other religion & $\begin{array}{l}0.318^{* * *} \\
(0.048)\end{array}$ & $\begin{array}{r}-0.115^{*} \\
(0.059)\end{array}$ & $\begin{array}{c}-0.079 \\
(0.049)\end{array}$ & $\begin{array}{l}0.027^{* *} \\
(0.012)\end{array}$ & $\begin{array}{r}0.040^{*} \\
(0.021)\end{array}$ & $\begin{array}{l}0.207^{* * *} \\
(0.066)\end{array}$ \\
\hline employed & $\begin{array}{r}-0.027 \\
(0.024)\end{array}$ & $\begin{array}{c}-0.065^{* *} \\
(0.029)\end{array}$ & $\begin{array}{l}-0.082^{* * *} \\
(0.023)\end{array}$ & $\begin{array}{l}0.015^{* * *} \\
(0.005)\end{array}$ & $\begin{array}{c}-0.005 \\
(0.007)\end{array}$ & $\begin{array}{c}0.021 \\
(0.024)\end{array}$ \\
\hline income & $\begin{array}{l}0.059^{* * *} \\
(0.010)\end{array}$ & $\begin{array}{c}-0.058^{* * *} \\
(0.009)\end{array}$ & $\begin{array}{c}-0.117^{* * *} \\
(0.010)\end{array}$ & $\begin{array}{c}-0.001 \\
(0.001)\end{array}$ & $\begin{array}{c}0.006^{*} \\
(0.003)\end{array}$ & $\begin{array}{l}0.058^{* * *} \\
(0.009)\end{array}$ \\
\hline male & $\begin{array}{l}0.068^{* * *} \\
(0.023)\end{array}$ & $\begin{array}{c}-0.263^{* * *} \\
(0.029)\end{array}$ & $\begin{array}{c}-0.105^{* * *} \\
(0.018)\end{array}$ & $\begin{array}{l}0.115^{* * *} \\
(0.007)\end{array}$ & $\begin{array}{l}0.036^{* * *} \\
(0.007)\end{array}$ & $\begin{array}{c}-0.127^{* * *} \\
(0.032)\end{array}$ \\
\hline health & $\begin{array}{l}0.090^{* * *} \\
(0.012)\end{array}$ & $\begin{array}{c}-0.136^{* * *} \\
(0.017)\end{array}$ & $\begin{array}{c}-0.113^{* * *} \\
(0.017)\end{array}$ & $\begin{array}{l}0.020^{* * *} \\
(0.003)\end{array}$ & $\begin{array}{l}0.036^{* * *} \\
(0.004)\end{array}$ & $\begin{array}{l}0.121^{\text {*** }} \\
(0.015)\end{array}$ \\
\hline secondary & $\begin{array}{c}-0.117^{* *} \\
(0.051)\end{array}$ & $\begin{array}{c}-0.180^{* * *} \\
(0.044)\end{array}$ & $\begin{array}{c}-0.263^{* * *} \\
(0.037)\end{array}$ & $\begin{array}{l}0.021^{* * *} \\
(0.008)\end{array}$ & $\begin{array}{l}0.055^{* * *} \\
(0.011)\end{array}$ & $\begin{array}{l}0.114^{* * *} \\
(0.034)\end{array}$ \\
\hline university & $\begin{array}{c}-0.271^{* * *} \\
(0.063)\end{array}$ & $\begin{array}{c}-0.427^{* * *} \\
(0.062)\end{array}$ & $\begin{array}{c}-0.369^{* * *} \\
(0.052)\end{array}$ & $\begin{array}{c}-0.003 \\
(0.011)\end{array}$ & $\begin{array}{l}0.170^{* * *} \\
(0.019)\end{array}$ & $\begin{array}{l}0.166^{* * *} \\
(0.045)\end{array}$ \\
\hline Country dummies & $\checkmark$ & $\checkmark$ & $\checkmark$ & $\checkmark$ & $\checkmark$ & $\checkmark$ \\
\hline Country/wave dummies & $\checkmark$ & $\checkmark$ & $\checkmark$ & $\checkmark$ & $\checkmark$ & $\checkmark$ \\
\hline Wave dummies & $\checkmark$ & $\checkmark$ & $\checkmark$ & $\checkmark$ & $\checkmark$ & $\checkmark$ \\
\hline Demog. controls & $\checkmark$ & $\checkmark$ & $\checkmark$ & $\checkmark$ & $\checkmark$ & $\checkmark$ \\
\hline R-sq & 0.108 & 0.102 & 0.116 & 0.114 & 0.113 & 0.081 \\
\hline Number of observations & 128108.000 & 157213.000 & 165123.000 & 139251.000 & 156135.000 & 131584.000 \\
\hline
\end{tabular}

Notes: OLS - Coefficients are reported. Country clustered standard errors are in parentheses. Demographic controls include age, age squared, whether the respondent is married and urban residency. The dependent variables are the respondent's self-position on a left-right scale, opinion about private vs. state ownership of business, opinion about government responsibility, whether the respondent is willing to fight for his/her country, opinion about democracy, and opinion whether wealth accumulation can only happen at the expense of others. Significance levels: * $p<0.1,{ }^{* *} p<0.05,{ }^{* * *} p<0.01$. 


\section{ONLINE APPENDIX: NOT FOR PUBLICATION}


Table A1: Prevalence of each Christian denomination by country: World Values Survey

\begin{tabular}{|c|c|c|c|c|}
\hline country & orthodox & catholic & protestant & other \\
\hline \multirow[t]{2}{*}{ Albania } & 0.10 & 0.33 & 0.09 & 0.41 \\
\hline & 0.30 & 0.47 & 0.29 & 0.49 \\
\hline \multirow[t]{2}{*}{ Algeria } & 0.00 & 0.00 & 0.00 & 1.00 \\
\hline & 0.00 & 0.00 & 0.00 & 0.00 \\
\hline \multirow[t]{2}{*}{ Andorra } & 0.00 & 0.54 & 0.01 & 0.03 \\
\hline & 0.05 & 0.50 & 0.10 & 0.17 \\
\hline \multirow[t]{2}{*}{ Argentina } & 0.00 & 0.75 & 0.02 & 0.07 \\
\hline & 0.03 & 0.44 & 0.15 & 0.26 \\
\hline \multirow[t]{2}{*}{ Armenia } & 0.00 & 0.00 & 0.00 & 0.89 \\
\hline & 0.00 & 0.07 & 0.04 & 0.32 \\
\hline \multirow[t]{2}{*}{ Australia } & 0.02 & 0.25 & 0.37 & 0.05 \\
\hline & 0.13 & 0.43 & 0.48 & 0.22 \\
\hline \multirow[t]{2}{*}{ Azerbaijan } & 0.02 & 0.00 & 0.00 & 0.93 \\
\hline & 0.13 & 0.03 & 0.04 & 0.25 \\
\hline \multicolumn{5}{|l|}{ Bahrain } \\
\hline \multirow[t]{2}{*}{ Bangladesh } & 0.00 & 0.01 & 0.00 & 0.99 \\
\hline & 0.02 & 0.07 & 0.03 & 0.09 \\
\hline \multirow[t]{2}{*}{ Belarus } & 0.64 & 0.09 & 0.01 & 0.00 \\
\hline & 0.48 & 0.28 & 0.09 & 0.06 \\
\hline \multirow[t]{2}{*}{ Bosnia } & 0.13 & 0.16 & 0.00 & 0.41 \\
\hline & 0.33 & 0.36 & 0.03 & 0.49 \\
\hline \multirow[t]{2}{*}{ Brazil } & 0.00 & 0.57 & 0.25 & 0.05 \\
\hline & 0.04 & 0.50 & 0.43 & 0.22 \\
\hline \multirow[t]{2}{*}{ Bulgaria } & 0.63 & 0.01 & 0.00 & 0.11 \\
\hline & 0.48 & 0.08 & 0.07 & 0.32 \\
\hline \multirow{2}{*}{ Burkina Faso } & 0.00 & 0.31 & 0.08 & 0.60 \\
\hline & 0.04 & 0.46 & 0.27 & 0.49 \\
\hline \multirow[t]{2}{*}{ Canada } & 0.01 & 0.41 & 0.20 & 0.10 \\
\hline & 0.09 & 0.49 & 0.40 & 0.30 \\
\hline \multirow[t]{2}{*}{ Chile } & 0.00 & 0.62 & 0.12 & 0.02 \\
\hline & 0.02 & 0.48 & 0.33 & 0.14 \\
\hline \multirow[t]{2}{*}{ China } & 0.00 & 0.01 & 0.03 & 0.08 \\
\hline & 0.00 & 0.07 & 0.18 & 0.27 \\
\hline \multirow[t]{2}{*}{ Colombia } & 0.01 & 0.78 & 0.05 & 0.04 \\
\hline & 0.11 & 0.41 & 0.22 & 0.20 \\
\hline \multirow{2}{*}{ Croatia } & 0.01 & 0.84 & 0.00 & 0.02 \\
\hline & 0.11 & 0.36 & 0.06 & 0.13 \\
\hline \multirow[t]{2}{*}{ Cyprus } & 0.48 & 0.00 & 0.00 & 0.46 \\
\hline & 0.50 & 0.07 & 0.04 & 0.50 \\
\hline \multirow[t]{2}{*}{ Czech Rep. } & 0.00 & 0.42 & 0.02 & 0.00 \\
\hline & 0.00 & 0.49 & 0.15 & 0.00 \\
\hline Dominican Rep. & 0.00 & 0.60 & 0.12 & 0.04 \\
\hline & 0.00 & 0.49 & 0.32 & 0.21 \\
\hline Ecuador & 0.00 & 0.63 & 0.12 & 0.02 \\
\hline & 0.00 & 0.48 & 0.32 & 0.14 \\
\hline Egypt & 0.00 & 0.00 & 0.00 & 1.00 \\
\hline & 0.00 & 0.00 & 0.00 & 0.00 \\
\hline El Salvador & 0.00 & 0.59 & 0.23 & 0.02 \\
\hline & 0.00 & 0.49 & 0.42 & 0.15 \\
\hline Estonia & 0.21 & 0.01 & 0.09 & 0.01 \\
\hline & 0.41 & 0.11 & 0.28 & 0.11 \\
\hline
\end{tabular}

Source: World Values Survey, 1995-2014. For each country means (first row) and standard deviations (second row) are reported. 
Prevalence of each Christian denomination by country: World Values Survey, continued

\begin{tabular}{|c|c|c|c|c|}
\hline country & orthodox & catholic & protestant & other \\
\hline \multirow[t]{2}{*}{ Ethiopia } & 0.00 & 0.02 & 0.20 & 0.78 \\
\hline & 0.00 & 0.12 & 0.40 & 0.41 \\
\hline \multirow[t]{2}{*}{ Finland } & 0.02 & 0.02 & 0.82 & 0.02 \\
\hline & 0.12 & 0.13 & 0.38 & 0.13 \\
\hline \multirow[t]{2}{*}{ France } & 0.00 & 0.41 & 0.02 & 0.06 \\
\hline & 0.04 & 0.49 & 0.15 & 0.24 \\
\hline \multirow[t]{2}{*}{ Georgia } & 0.90 & 0.01 & 0.00 & 0.06 \\
\hline & 0.30 & 0.09 & 0.03 & 0.23 \\
\hline \multirow[t]{2}{*}{ Germany } & 0.01 & 0.21 & 0.30 & 0.02 \\
\hline & 0.08 & 0.41 & 0.46 & 0.15 \\
\hline \multirow[t]{2}{*}{ Ghana } & 0.07 & 0.17 & 0.57 & 0.17 \\
\hline & 0.25 & 0.38 & 0.50 & 0.38 \\
\hline \multirow[t]{2}{*}{ Great Britain } & 0.00 & 0.10 & 0.29 & 0.11 \\
\hline & 0.06 & 0.31 & 0.46 & 0.31 \\
\hline \multirow[t]{2}{*}{ Guatemala } & 0.00 & 0.56 & 0.31 & 0.04 \\
\hline & 0.00 & 0.50 & 0.46 & 0.19 \\
\hline \multirow[t]{2}{*}{ Hong Kong } & 0.00 & 0.03 & 0.05 & 0.21 \\
\hline & 0.00 & 0.17 & 0.21 & 0.41 \\
\hline \multirow[t]{2}{*}{ Hungary } & 0.01 & 0.53 & 0.18 & 0.02 \\
\hline & 0.10 & 0.50 & 0.38 & 0.12 \\
\hline \multirow[t]{2}{*}{ India } & 0.00 & 0.02 & 0.01 & 0.94 \\
\hline & 0.00 & 0.13 & 0.10 & 0.24 \\
\hline \multirow[t]{2}{*}{ Indonesia } & 0.00 & 0.02 & 0.05 & 0.93 \\
\hline & 0.00 & 0.15 & 0.21 & 0.25 \\
\hline \multirow[t]{2}{*}{ Iran } & 0.00 & 0.00 & 0.00 & 0.99 \\
\hline & 0.00 & 0.00 & 0.00 & 0.09 \\
\hline \multirow[t]{2}{*}{ Iraq } & 0.00 & 0.00 & 0.00 & 1.00 \\
\hline & 0.04 & 0.05 & 0.02 & 0.07 \\
\hline \multirow[t]{2}{*}{ Israel } & 0.00 & 0.00 & 0.00 & 1.00 \\
\hline & 0.00 & 0.00 & 0.00 & 0.00 \\
\hline \multirow[t]{2}{*}{ Italy } & 0.00 & 0.88 & 0.00 & 0.00 \\
\hline & 0.00 & 0.33 & 0.00 & 0.07 \\
\hline \multirow[t]{2}{*}{ Japan } & 0.00 & 0.01 & 0.01 & 0.40 \\
\hline & 0.05 & 0.08 & 0.08 & 0.49 \\
\hline \multirow[t]{2}{*}{ Jordan } & 0.01 & 0.01 & 0.00 & 0.98 \\
\hline & 0.07 & 0.09 & 0.05 & 0.12 \\
\hline \multirow[t]{2}{*}{ Kazakhstan } & 0.27 & 0.01 & 0.01 & 0.52 \\
\hline & 0.44 & 0.10 & 0.08 & 0.50 \\
\hline \multicolumn{5}{|l|}{ Kuwait } \\
\hline \multirow[t]{2}{*}{ Kyrgyzstan } & 0.07 & 0.00 & 0.01 & 0.85 \\
\hline & 0.25 & 0.06 & 0.08 & 0.36 \\
\hline Latvia & 0.19 & 0.20 & 0.21 & 0.01 \\
\hline & 0.39 & 0.40 & 0.41 & 0.08 \\
\hline Lebanon & 0.00 & 0.23 & 0.01 & 0.76 \\
\hline & 0.00 & 0.42 & 0.11 & 0.43 \\
\hline Libya & 0.00 & 0.00 & 0.00 & 1.00 \\
\hline & 0.00 & 0.00 & 0.00 & 0.00 \\
\hline Lithuania & 0.04 & 0.80 & 0.02 & 0.01 \\
\hline & 0.20 & 0.40 & 0.14 & 0.07 \\
\hline Macedonia & 0.53 & 0.00 & 0.00 & 0.25 \\
\hline & 0.50 & 0.07 & 0.05 & 0.43 \\
\hline
\end{tabular}

Source: World Values Survey, 1995-2014. 
Prevalence of each Christian denomination by country: World Values Survey, continued

\begin{tabular}{|c|c|c|c|c|}
\hline country & orthodox & catholic & protestant & other \\
\hline \multirow[t]{2}{*}{ Malaysia } & 0.00 & 0.03 & 0.02 & 0.93 \\
\hline & 0.00 & 0.18 & 0.15 & 0.26 \\
\hline \multirow[t]{2}{*}{ Mali } & 0.00 & 0.02 & 0.01 & 0.97 \\
\hline & 0.03 & 0.13 & 0.07 & 0.16 \\
\hline \multirow[t]{2}{*}{ Mexico } & 0.00 & 0.69 & 0.08 & 0.03 \\
\hline & 0.00 & 0.46 & 0.27 & 0.17 \\
\hline \multirow[t]{2}{*}{ Moldova } & 0.90 & 0.01 & 0.02 & 0.01 \\
\hline & 0.30 & 0.12 & 0.13 & 0.10 \\
\hline \multirow{2}{*}{ Montenegro } & 0.69 & 0.06 & 0.00 & 0.21 \\
\hline & 0.46 & 0.24 & 0.04 & 0.41 \\
\hline \multirow[t]{2}{*}{ Morocco } & 0.00 & 0.00 & 0.00 & 1.00 \\
\hline & 0.02 & 0.02 & 0.02 & 0.03 \\
\hline \multirow[t]{2}{*}{ Netherlands } & 0.02 & 0.21 & 0.12 & 0.08 \\
\hline & 0.14 & 0.41 & 0.32 & 0.27 \\
\hline \multirow[t]{2}{*}{ New Zealand } & 0.00 & 0.14 & 0.51 & 0.09 \\
\hline & 0.03 & 0.35 & 0.50 & 0.29 \\
\hline \multirow[t]{2}{*}{ Nigeria } & 0.01 & 0.15 & 0.23 & 0.58 \\
\hline & 0.08 & 0.36 & 0.42 & 0.49 \\
\hline \multirow[t]{2}{*}{ Norway } & 0.00 & 0.01 & 0.74 & 0.04 \\
\hline & 0.07 & 0.11 & 0.44 & 0.20 \\
\hline \multirow[t]{2}{*}{ Pakistan } & 0.00 & 0.00 & 0.00 & 0.85 \\
\hline & 0.00 & 0.00 & 0.00 & 0.36 \\
\hline \multirow[t]{2}{*}{ Palestine } & 0.00 & 0.00 & 0.00 & 1.00 \\
\hline & 0.00 & 0.04 & 0.00 & 0.04 \\
\hline \multirow[t]{2}{*}{ Peru } & 0.00 & 0.78 & 0.11 & 0.03 \\
\hline & 0.00 & 0.41 & 0.31 & 0.17 \\
\hline \multirow[t]{2}{*}{ Philippines } & 0.00 & 0.75 & 0.05 & 0.13 \\
\hline & 0.00 & 0.43 & 0.21 & 0.33 \\
\hline \multirow[t]{2}{*}{ Poland } & 0.01 & 0.94 & 0.01 & 0.00 \\
\hline & 0.10 & 0.23 & 0.09 & 0.07 \\
\hline \multirow[t]{2}{*}{ Puerto Rico } & 0.00 & 0.57 & 0.15 & 0.11 \\
\hline & 0.00 & 0.49 & 0.36 & 0.32 \\
\hline \multicolumn{5}{|l|}{ Qatar } \\
\hline \multirow[t]{2}{*}{ Romania } & 0.88 & 0.06 & 0.05 & 0.01 \\
\hline & 0.33 & 0.23 & 0.23 & 0.08 \\
\hline \multirow[t]{2}{*}{ Russia } & 0.57 & 0.00 & 0.01 & 0.06 \\
\hline & 0.50 & 0.05 & 0.09 & 0.25 \\
\hline \multirow[t]{2}{*}{ Rwanda } & 0.01 & 0.54 & 0.25 & 0.13 \\
\hline & 0.10 & 0.50 & 0.43 & 0.34 \\
\hline \multirow[t]{2}{*}{ Saudi Arabia } & 0.00 & 0.00 & 0.00 & 1.00 \\
\hline & 0.00 & 0.00 & 0.00 & 0.04 \\
\hline \multirow[t]{2}{*}{ Serbia } & 0.74 & 0.06 & 0.01 & 0.07 \\
\hline & 0.44 & 0.24 & 0.08 & 0.25 \\
\hline Serbia and Monte & 0.88 & 0.04 & 0.01 & 0.03 \\
\hline & 0.32 & 0.20 & 0.09 & 0.18 \\
\hline Singapore & 0.00 & 0.07 & 0.09 & 0.68 \\
\hline & 0.00 & 0.25 & 0.29 & 0.47 \\
\hline Slovakia & $0.00 \quad 4$ & 0.76 & 0.10 & 0.01 \\
\hline & 0.05 & 0.43 & 0.30 & 0.09 \\
\hline
\end{tabular}

Source: World Values Survey, 1995-2014. 
Prevalence of each Christian denomination by country: World Values Survey, continued

\begin{tabular}{|c|c|c|c|c|}
\hline country & orthodox & catholic & protestant & other \\
\hline \multirow[t]{2}{*}{ Slovenia } & 0.02 & 0.68 & 0.02 & 0.02 \\
\hline & 0.14 & 0.47 & 0.13 & 0.13 \\
\hline \multirow[t]{2}{*}{ South Africa } & 0.01 & 0.13 & 0.43 & 0.29 \\
\hline & 0.08 & 0.34 & 0.50 & 0.45 \\
\hline \multirow[t]{2}{*}{ South Korea } & 0.00 & 0.16 & 0.22 & 0.25 \\
\hline & 0.07 & 0.37 & 0.41 & 0.43 \\
\hline \multirow[t]{2}{*}{ Spain } & 0.00 & 0.80 & 0.01 & 0.01 \\
\hline & 0.03 & 0.40 & 0.08 & 0.12 \\
\hline \multirow[t]{2}{*}{ Sweden } & 0.00 & 0.02 & 0.70 & 0.05 \\
\hline & 0.06 & 0.13 & 0.46 & 0.22 \\
\hline \multirow[t]{2}{*}{ Switzerland } & 0.00 & 0.48 & 0.37 & 0.04 \\
\hline & 0.05 & 0.50 & 0.48 & 0.20 \\
\hline \multirow[t]{2}{*}{ Taiwan } & 0.08 & 0.01 & 0.04 & 0.63 \\
\hline & 0.27 & 0.11 & 0.20 & 0.48 \\
\hline \multirow[t]{2}{*}{ Tanzania } & 0.05 & 0.28 & 0.19 & 0.46 \\
\hline & 0.22 & 0.45 & 0.39 & 0.50 \\
\hline \multirow[t]{2}{*}{ Thailand } & 0.00 & 0.00 & 0.00 & 0.99 \\
\hline & 0.00 & 0.05 & 0.03 & 0.08 \\
\hline \multirow[t]{2}{*}{ Trinidad and Tob } & 0.00 & 0.20 & 0.43 & 0.30 \\
\hline & 0.06 & 0.40 & 0.50 & 0.46 \\
\hline \multirow[t]{2}{*}{ Tunisia } & 0.00 & 0.00 & 0.00 & 1.00 \\
\hline & 0.00 & 0.00 & 0.00 & 0.00 \\
\hline \multirow[t]{2}{*}{ Turkey } & 0.00 & 0.00 & 0.00 & 0.94 \\
\hline & 0.02 & 0.02 & 0.02 & 0.25 \\
\hline \multirow[t]{2}{*}{ Uganda } & 0.00 & 0.37 & 0.44 & 0.18 \\
\hline & 0.06 & 0.48 & 0.50 & 0.38 \\
\hline \multirow{2}{*}{ Ukraine } & 0.64 & 0.07 & 0.01 & 0.01 \\
\hline & 0.48 & 0.25 & 0.09 & 0.10 \\
\hline \multirow[t]{2}{*}{ United States } & 0.00 & 0.23 & 0.31 & 0.20 \\
\hline & 0.06 & 0.42 & 0.46 & 0.40 \\
\hline \multirow[t]{2}{*}{ Uruguay } & 0.00 & 0.34 & 0.07 & 0.05 \\
\hline & 0.00 & 0.47 & 0.25 & 0.23 \\
\hline \multirow[t]{2}{*}{ Uzbekistan } & 0.03 & 0.00 & 0.00 & 0.96 \\
\hline & 0.17 & 0.03 & 0.05 & 0.20 \\
\hline \multirow[t]{2}{*}{ Venezuela } & 0.00 & 0.75 & 0.07 & 0.01 \\
\hline & 0.03 & 0.43 & 0.25 & 0.09 \\
\hline \multirow[t]{2}{*}{ Viet Nam } & 0.00 & 0.06 & 0.01 & 0.62 \\
\hline & 0.02 & 0.24 & 0.10 & 0.49 \\
\hline \multirow[t]{2}{*}{ Yemen } & 0.00 & 0.00 & 0.00 & 1.00 \\
\hline & 0.00 & 0.00 & 0.00 & 0.00 \\
\hline \multirow[t]{2}{*}{ Zambia } & 0.00 & 0.34 & 0.46 & 0.14 \\
\hline & 0.04 & 0.47 & 0.50 & 0.35 \\
\hline \multirow[t]{2}{*}{ Zimbabwe } & 0.01 & 0.19 & 0.59 & 0.12 \\
\hline & 0.08 & 0.39 & 0.49 & 0.32 \\
\hline
\end{tabular}

Source: World Values Survey, 1995-2014. 
Table A2: Prevalence of each Christian denomination by country: Life in Transition Survey

\begin{tabular}{|c|c|c|c|c|}
\hline country & orthodox & catholic & protestant & other \\
\hline \multirow[t]{2}{*}{ Albania } & 0.14 & 0.06 & 0.00 & 0.79 \\
\hline & 0.35 & 0.23 & 0.07 & 0.41 \\
\hline \multirow[t]{2}{*}{ Armenia } & 0.00 & 0.00 & 0.00 & 0.99 \\
\hline & 0.00 & 0.03 & 0.03 & 0.09 \\
\hline \multirow[t]{2}{*}{ Azerbaijan } & 0.00 & 0.00 & 0.01 & 0.99 \\
\hline & 0.03 & 0.03 & 0.07 & 0.08 \\
\hline \multirow[t]{2}{*}{ Belarus } & 0.83 & 0.10 & 0.01 & 0.01 \\
\hline & 0.38 & 0.29 & 0.08 & 0.11 \\
\hline \multirow[t]{2}{*}{ Bosnia } & 0.37 & 0.12 & 0.00 & 0.50 \\
\hline & 0.48 & 0.32 & 0.00 & 0.50 \\
\hline \multirow[t]{2}{*}{ Bulgaria } & 0.86 & 0.01 & 0.00 & 0.11 \\
\hline & 0.35 & 0.08 & 0.03 & 0.32 \\
\hline \multirow[t]{2}{*}{ Croatia } & 0.08 & 0.84 & 0.00 & 0.02 \\
\hline & 0.27 & 0.37 & 0.06 & 0.14 \\
\hline \multirow[t]{2}{*}{ Czech Republic } & 0.01 & 0.22 & 0.02 & 0.02 \\
\hline & 0.12 & 0.42 & 0.13 & 0.12 \\
\hline \multirow[t]{2}{*}{ Estonia } & 0.24 & 0.01 & 0.27 & 0.04 \\
\hline & 0.43 & 0.09 & 0.45 & 0.20 \\
\hline \multirow[t]{2}{*}{ France } & 0.01 & 0.61 & 0.03 & 0.05 \\
\hline & 0.08 & 0.49 & 0.16 & 0.21 \\
\hline \multirow[t]{2}{*}{ Georgia } & 0.92 & 0.00 & 0.00 & 0.06 \\
\hline & 0.27 & 0.00 & 0.04 & 0.25 \\
\hline \multirow[t]{2}{*}{ Germany } & 0.04 & 0.33 & 0.36 & 0.03 \\
\hline & 0.20 & 0.47 & 0.48 & 0.17 \\
\hline \multirow[t]{2}{*}{ Great Britain } & 0.06 & 0.10 & 0.49 & 0.11 \\
\hline & 0.24 & 0.30 & 0.50 & 0.31 \\
\hline \multirow[t]{2}{*}{ Hungary } & 0.01 & 0.67 & 0.14 & 0.07 \\
\hline & 0.08 & 0.47 & 0.35 & 0.25 \\
\hline \multirow[t]{2}{*}{ Italy } & 0.01 & 0.87 & 0.01 & 0.03 \\
\hline & 0.08 & 0.33 & 0.09 & 0.17 \\
\hline \multirow[t]{2}{*}{ Kazakhstan } & 0.44 & 0.00 & 0.01 & 0.45 \\
\hline & 0.50 & 0.06 & 0.11 & 0.50 \\
\hline \multirow[t]{2}{*}{ Kosovo } & 0.14 & 0.00 & 0.00 & 0.86 \\
\hline & 0.34 & 0.06 & 0.00 & 0.35 \\
\hline \multirow[t]{2}{*}{ Kyrgyzstan } & 0.11 & 0.00 & 0.00 & 0.87 \\
\hline & 0.31 & 0.00 & 0.07 & 0.34 \\
\hline \multirow[t]{2}{*}{ Latvia } & 0.32 & 0.22 & 0.28 & 0.06 \\
\hline & 0.47 & 0.41 & 0.45 & 0.24 \\
\hline \multirow[t]{2}{*}{ Lithuania } & 0.02 & 0.90 & 0.02 & 0.03 \\
\hline & 0.14 & 0.30 & 0.14 & 0.18 \\
\hline \multirow[t]{2}{*}{ Macedonia } & 0.65 & 0.00 & 0.00 & 0.34 \\
\hline & 0.48 & 0.05 & 0.00 & 0.47 \\
\hline \multirow[t]{2}{*}{ Moldova } & 0.96 & 0.00 & 0.00 & 0.02 \\
\hline & 0.19 & 0.03 & 0.07 & 0.15 \\
\hline Mongolia & 0.00 & 0.00 & 0.03 & 0.73 \\
\hline & 0.00 & 0.00 & 0.16 & 0.44 \\
\hline Montenegro & 0.74 & 0.03 & 0.00 & 0.21 \\
\hline & 0.44 & 0.16 & 0.07 & 0.40 \\
\hline
\end{tabular}

Source: Life in Transition SuAtrey 2010. For each country means (first row) and standard deviations (second row) are reported. 
Prevalence of each Christian denomination by country: Life in Transition Survey

\begin{tabular}{lrrrr}
\hline country & orthodox & catholic & protestant & other \\
\hline Poland & 0.01 & 0.95 & 0.00 & 0.01 \\
Romania & 0.09 & 0.21 & 0.05 & 0.11 \\
& 0.89 & 0.05 & 0.03 & 0.03 \\
Russia & 0.31 & 0.21 & 0.16 & 0.16 \\
& 0.84 & 0.00 & 0.01 & 0.06 \\
Serbia & 0.37 & 0.00 & 0.07 & 0.23 \\
& 0.88 & 0.05 & 0.01 & 0.03 \\
Slovakia & 0.33 & 0.22 & 0.09 & 0.18 \\
& 0.00 & 0.71 & 0.06 & 0.03 \\
Slovenia & 0.07 & 0.46 & 0.24 & 0.18 \\
& 0.03 & 0.69 & 0.01 & 0.05 \\
Sweden & 0.18 & 0.46 & 0.11 & 0.23 \\
& 0.02 & 0.02 & 0.66 & 0.04 \\
Tajikistan & 0.12 & 0.16 & 0.47 & 0.19 \\
& 0.01 & 0.00 & 0.00 & 0.99 \\
Ukraine & 0.12 & 0.00 & 0.00 & 0.12 \\
& 0.83 & 0.08 & 0.02 & 0.02 \\
Uzbekistan & 0.38 & 0.26 & 0.14 & 0.15 \\
& 0.02 & 0.00 & 0.02 & 0.96 \\
& 0.12 & 0.00 & 0.13 & 0.19 \\
\hline Source: & & 0.016
\end{tabular}

Source: Life in Transition Survey 2010. 